\title{
The Education of the Art Market: National Schools and International Trade in the "Long" Nineteenth Century
}

\author{
Jan Dirk Baetens and Dries Lyna
}

When the Prussian army threatened to lay siege to Paris in 1870 during the Franco-Prussian War, the famous French art dealer Paul Durand-Ruel rapidly packed up his paintings and shipped them to London. Making his way to the British capital 'just before the gates of Paris were shut,' Durand-Ruel lost no time in setting up a new business across the Channel. In his temporary new home London, he was assisted by Henry Wallis, a dealer closely associated with the famous art mogul Ernest Gambart. Durand-Ruel's London gallery space was capacious, well located and - above all — at a safe distance from the Prussian invaders in France. There was, however, one unhappy feature, as the dealer noted much later in his memoirs: 'by an unfortunate coincidence [it] was called “The German Gallery."'

\section{National Art, International Markets}

The 'unfortunate coincidence' described by Durand-Ruel is more than an ironic footnote in the history of the nineteenth-century art market. It was certainly not a coincidence that the dealer's new gallery carried a name that apparently referred to a specific foreign "school" of art, albeit not the one that he intended to market in London. Nor was it a coincidence that Durand-Ruel apparently did not hesitate to set up his business in London, even with a stock of paintings, mostly belonging to the so-called "School of 1830," that were generally considered as quintessentially French and, more importantly, that were only beginning to be accepted as serious art even in his own country.

Rather, Durand-Ruel's relatively easy move from one country to another and the (inter)national name of his new gallery space seem typical of the state of the European art market of the time. The exponential growth of the art market

1 Paul Durand-Ruel, Memoirs of the First Impressionist Art Dealer(1831-1922) (Paris: Flammarion, 2014), 78 .

(C) JAN DIRK BAETENS AND DRIES LYNA, 2019 | DOI:10.1163/9789004291997_003

This is an open access chapter distributed under the terms of the prevailing CC-BY-NC License at the time of publication. 
in the preceding decades had created important commercial opportunities from which enterprising dealers and other middlemen like Durand-Ruel, increasingly operating on an international scale, could benefit. In addition, a body of knowledge and art discourse centring on notions of national identity had been created, facilitating this process of internationalisation and making artists, dealers and other agents increasingly aware of the commercial potential of marketing art with reference to these notions, or even as actual national "brands." Thus, upon his arrival in London, Durand-Ruel could fall back on an extensive network that he and his father had started to develop in the $1850 \mathrm{~s}$ and 1860 s and that had already led to a great number of international sales and purchases involving most of the leading galleries in London, including Agnew's, McLean's and, of course, Gambart's gallery. ${ }^{2}$ The name of his London premises, on the other hand, the German Gallery, testifies to the essential role played by national labels and conceptual categories in this process of internationalisation. Indeed, when Durand-Ruel arrived in the British capital, many galleries were named after specific national schools and regularly also specialised in the work of these schools. Most of them had taken their cue from Ernest Gambart, who, in 1854, became the first to successfully promote a specific national "brand" of painting when he established the popular and highly lucrative French Gallery and thus presented himself as an international arbiter of taste. By the last decades of the nineteenth century, the London art world boasted places like the German Gallery, the Belgian Gallery, the Dutch Gallery, the Continental Gallery and even the Japanese Gallery, and almost constituted, in Pamela Fletcher's terms, 'a Grand Tour on Bond Street,' allowing visitors to acquaint themselves with art coming from all the corners of Europe while staying within the bounds of the London art district around Bond Street. ${ }^{3}$

The reshaping of the London art district as a cosmopolitan centre of European art, all packed in easily identifiable national "brands," thus reflects the huge influx of foreign art into the British capital during the nineteenth century as well as, from a broader perspective, the general internationalisation of the art market. The development's structural dependence on national labels, visible amongst other things in the national denominations of gallery spaces, is also indicative of the importance of the binary of the "international" versus the "national" in that process. Indeed, the internationalisation of the

2 Anne Robbins, "À la conquête de Londres," in Paul Durand-Ruel. Le pari de l'impressionisme, ed. Sylvie Patry (Paris: Réunion des musées nationaux, 2014), 134-5.

3 Pamela Fletcher, "The Grand Tour on Bond Street: Cosmopolitanism and the Commercial Art Gallery in Victorian London," Visual Culture in Britain 12, no. 2 (2011): 139-53. 
art market in the nineteenth century went hand in hand with a sustained, and perhaps even increasing, emphasis on national conceptual categories, not only because the "international" logically suggests, and is meaningless without, its opposite term, the "national," but also because in the commercial logic of the time, both terms could mutually reinforce one another.

Some of Durand-Ruel's own business schemes can be used to illustrate this commercial dialectic. He sold art that was generally seen and promoted as typically French - mainly Barbizon landscapes and impressionist paintingsbut soon realised that the high commercial aims he had set for himself could not be achieved on the French market alone. Therefore, he tapped into the two most capitalised markets for contemporary art abroad: the British market, which he tried hard but ultimately failed to conquer, and, most importantly, the American market, where he did succeed in his goals. ${ }^{4}$ During his forced exile in London, he not only established contact with the exiled French impressionists who would assure his continuing fame in the history of nineteenth-century art, but he also set up a permanent business link between Paris and the British capital. This liaison would continue to serve him after his return to France, when he started selling his stock in London under the aegis of the newly founded Société des Artistes Français, assisted by another dealer from the circle of Gambart, the latter's nephew, Charles Deschamps. This new trading name indicates that Durand-Ruel was firmly aware of the commercial potential of national labels in this international environment. In his London gallery, he actively tried to stimulate the taste for French art by constructing an art-historical canon for the nineteenth-century French school, associating his stock of advanced painting with older, celebrated French masterpieces such as Jacques-Louis David's Death of Marat or Eugène Delacroix's Death of Sardanapulus, which he also put on show. He also made use, however, of the appeal of other national schools. British art, for instance, would on occasion be allowed in his London gallery because it attracted new audiences who could then compare the French and British schools. ${ }^{5}$ The appeal of these shows lay partly in the possibility of enjoying and judging art from the perspective of national identity, and Durand-Ruel clearly capitalised on it.

4 Robbins, "À la conquête de Londres," 134-49; Jennifer A. Thompson, "Paul Durand-Ruel et l'Amérique," in Paul Durand-Ruel. Le pari de l'impressionisme, 106-19.

5 Robbins, "À la conquête de Londres," 139-41. 


\section{Follow the Money: Lawrence Alma-Tadema's The Picture Gallery}

Ironically, much of the nineteenth-century state of affairs that had developed by the time Durand-Ruel temporarily set up shop in London is evoked in a painting depicting a scene set in classical antiquity. The Dutch-British artist Lawrence Alma-Tadema painted The Picture Gallery in 1874 for Ernest Gambart, who commissioned it together with its pendant, The Sculpture Gallery, for the sumptuous villa in Nice where he planned to spend his days after his retirement from the art business (Fig. 1.1). Both paintings show commercial selling spaces, a subject particularly apt as a tribute by Alma-Tadema to Gambart, who had introduced the artist's work into the British art market, stimulated him to move to London and remained his exclusive dealer until he retired to Nice, and had thus played a major role in the artist's extremely successful commercial career.

The Picture Gallery shows a Roman gallery filled with customers, attentively looking at the paintings hanging from top to bottom on the walls or studying an apparently exceptional painting displayed on an easel while sitting on chairs or on the comfortable soft bench in the middle of the gallery. As so often with Alma-Tadema's paintings, however, The Picture Gallery is far less concerned with ancient Rome than it is with the artist's own time: it depicts, under the guise of historical antiquity, a typical Victorian commercial exhibition space rather than an actual Roman gallery, visited by so-called "Victorians in toga" instead of real Romans. The art critic Joseph Beavington Atkinson accordingly observed that the walls in the gallery were 'completely filled with paintings, as they would be in a modern gallery' and seized the occasion to criticise the over-productive, profit-driven art market of his own time evoked by the abundance of paintings in the gallery: 'as if back then, as in the present, artists only painted to make their dealers' chimneys smoke.' ${ }^{6}$ Other critics easily recognised the painting's central figure as Gambart himself, in Roman dress, discussing the painting on the easel or simply praising his wares, while looking at the woman on the bench. ${ }^{7}$

What we may see in Alma-Tadema's painting, then, is Gambart's own London gallery, or at least a historical transposition of it. Indeed, on closer inspection, the gallery appears not to be visited by Roman amateurs but by major players in the Victorian art market of the time, all belonging to Gambart's circle. The two men in the back have been identified as Gambart's successors, P.J. Pilgeram and Léon Lefèvre, and the woman on the bench is probably 'Madame Angelée,'

6 Edwin Becker et al., eds., Sir Lawrence Alma-Tadema (Zwolle: Waanders, 1996), 187.

7 Id., 186. 


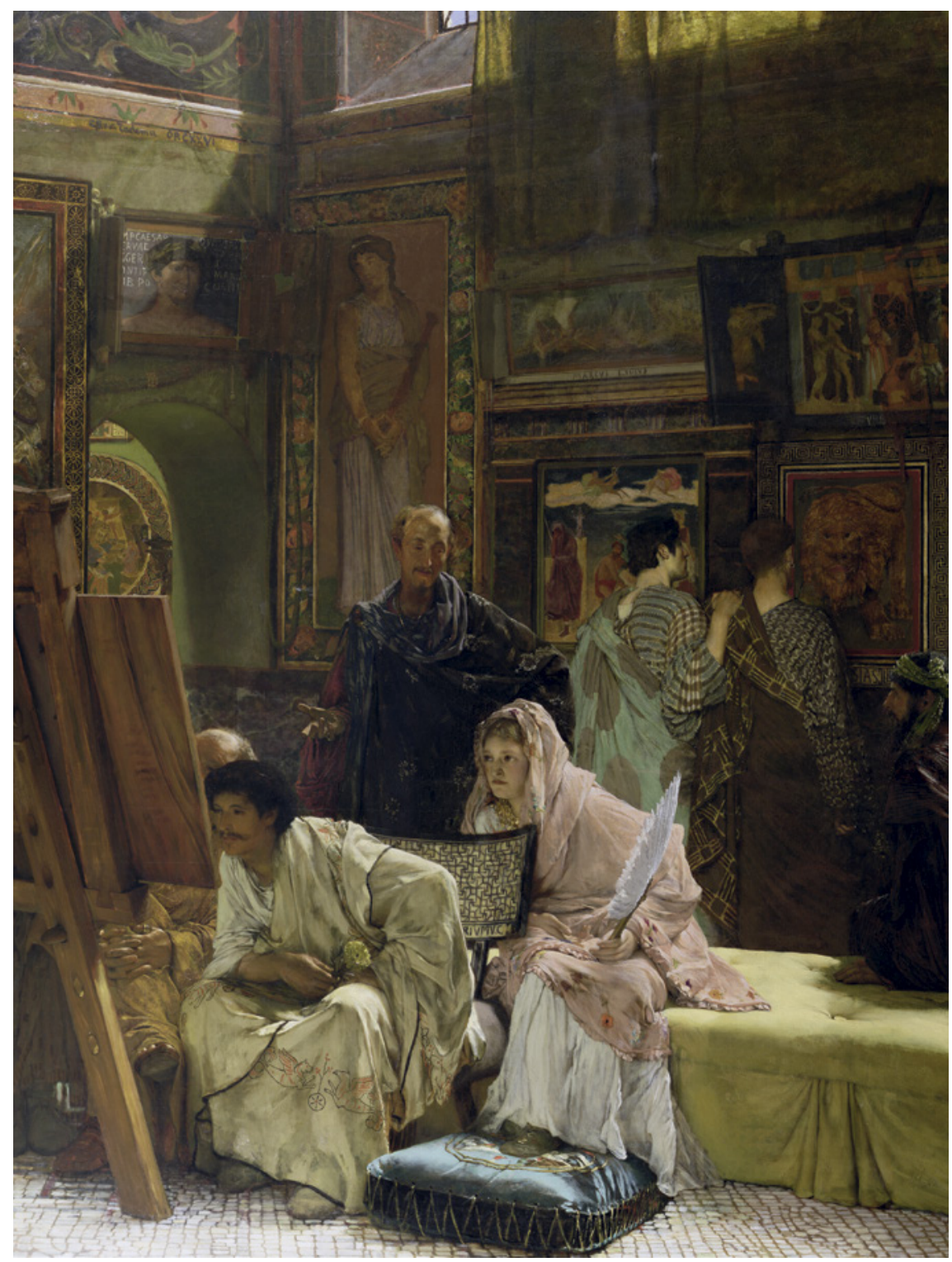

FIgURE 1.1 Lawrence Alma-Tadema, The Picture Gallery, 1874 . Oil on canvas, $218 \times 166 \mathrm{~cm}$. Towneley Hall Art Gallery \& Museum (C) COURTESY OF BURNLEY BOROUGH COUNCIL, TOWNELEY HALL ART GALLERY \& MUSEUM 
Gambart's mistress. Sitting next to her are Charles Deschamps, Gambart's nephew and agent to Durand-Ruel in London, and then, hardly visible behind the easel, Henry Wallis, who had first assisted Durand-Ruel upon his arrival in the British capital. The man on the extreme right, finally, has been identified, albeit tentatively, as Durand-Ruel himself. ${ }^{8}$

Gambart's gallery, or its historical other, is thus depicted as a veritable commercial powerhouse, with a network encompassing the whole of the London art world and extending far beyond to the European continent. This draws attention, again, to the paintings hanging on the walls, the products with which Gambart and his allies-or their classical alter egos-built their commercial empires. Many of these paintings are copies of frescoes in Pompeii and Herculaneum, which Alma-Tadema had studied in Italy. Elizabeth Prettejohn and others have pointed out that these Pompeian frescoes were, in their turn, usually copied from original Greek models, often the most celebrated paintings from classical Greece, now as in Alma-Tadema's time only known from literary sources. ${ }^{9}$ The work on the extreme left, for instance, almost completely cut off by the frame of Alma-Tadema's painting, can be identified by the spears and the horses, only just visible, as a version of The Battle of Issus, one of the most celebrated works of art from classical antiquity. The full-length portrait of Medea on the right-hand side of the doorway is a version of a mural in Herculaneum, itself thought to have been modelled after a lost work by the Greek painter Timomachos. In the lower register, just to the right of the centre of the composition, we see a version of The Sacrifice of Iphigenia, copied by Alma-Tadema after a fresco in Pompeii, itself a copy after a famous painting by the Greek artist Timanthes.

Prettejohn has suggested that the works of art in Alma-Tadema's painting should perhaps not be seen as (copies after) copies, but rather as the celebrated Greek originals themselves, brought together in a luxurious Roman commercial gallery. Alma-Tadema's scene can thus be read as a meta-reflection on issues of originality and reproduction, both central to the "copy-paste" practice that characterised the painter's reconstructions of classical antiquity on the basis of its material remains. ${ }^{10}$ However, originality and reproduction are also highly significant commercial markers. They were in fact central to the business model of virtually every successful Victorian artist,

8 Jeremy Maas, Gambart: Prince of the Victorian Art World (London: Barrie and Jenkins, 1975), 242; Vern G. Swanson, The Biography and Catalogue Raisonné of the Paintings of Sir Lawrence Alma-Tadema (London: Garton, 1990), 175. Swanson attributes the identification of Durand-Ruel to Maas, but it is unclear on what grounds.

9 Becker et al., eds., Sir Lawrence Alma-Tadema, 186-9.

10 Ibid. 
including Alma-Tadema. Nineteenth-century artists, both in Britain and on the Continent, often produced copies and variations of paintings in order to meet high market demands while also reducing production costs. ${ }^{11}$ Dealers invested in the production of copies and replicas because these were considered safe investments. ${ }^{12}$ Collectors sometimes expressly asked for replicas but could also insist on new and original compositions and be suspicious of works offered to them. According to Patricia Mainardi, the increased visibility of works of art in the exhibition and gallery circuit of the second half of the nineteenth century put a strain on this system, as it made it easier for collectors to find out about the existence of copies. ${ }^{13}$ The growing internationalisation of the art market, however, could release some of this pressure: collectors residing in different countries were less likely to find out that they possessed mere replicas or paintings very similar to those in other collections abroad. It is thus no coincidence that Vern Swanson's 1990 catalogue raisonné of Alma-Tadema's oeuvre lists-besides two versions in watercolour-no less than four variations of The Picture Gallery: one circulating in the British art market, one in Gambart's villa at the Côte d'Azur in France, one that was sold in 1878 to William H. Vanderbilt for his New York mansion, and one bought in 1875 by the Spanish aristocrat José de Murietta. ${ }^{14}$

The notions of reproduction and originality evoked in Alma-Tadema's painting can also be linked to the massive trade in engravings, lithographs, etchings and, as technology progressed, photographs. Hugely popular with the broader public, their commercial potential often surpassed that of the original paintings and allowed artists to sell the copyright on their work separately, regularly for a price higher than what was paid for the actual painting. The central importance of these reproductions for the businesses of Alma-Tadema and his peers is underlined in a cartoon that includes a lampooned version of The Picture Gallery. The illustration, published in Fun Magazine on the occasion of the 1874 Royal Academy exhibition, presents ridiculed versions of some of the most eye-catching paintings at the exhibition, including The Picture Gallery in the centre of the upper register (Fig. 1.2). It depicts these paintings, however, as prints or photographs thrown together in a messy pile, in other words as simple commodities in the commercial mass medium through which the vast majority of the public would encounter them. Both the production process of

11 Patricia Mainardi, "The 19th-Century Art Trade: Copies, Variations, Replicas," Van Gogh Museum Journal 6 (2000): 62-73.

12 Agnès Penot, La Maison Goupil. Galerie d'art internationale au XIXe siècle (Paris: Mare \& Martin, 2017), 157-63.

13 Id., 70.

14 Swanson, The Biography and Catalogue Raisonné, 144-5, 171-2, 175 and 178. 


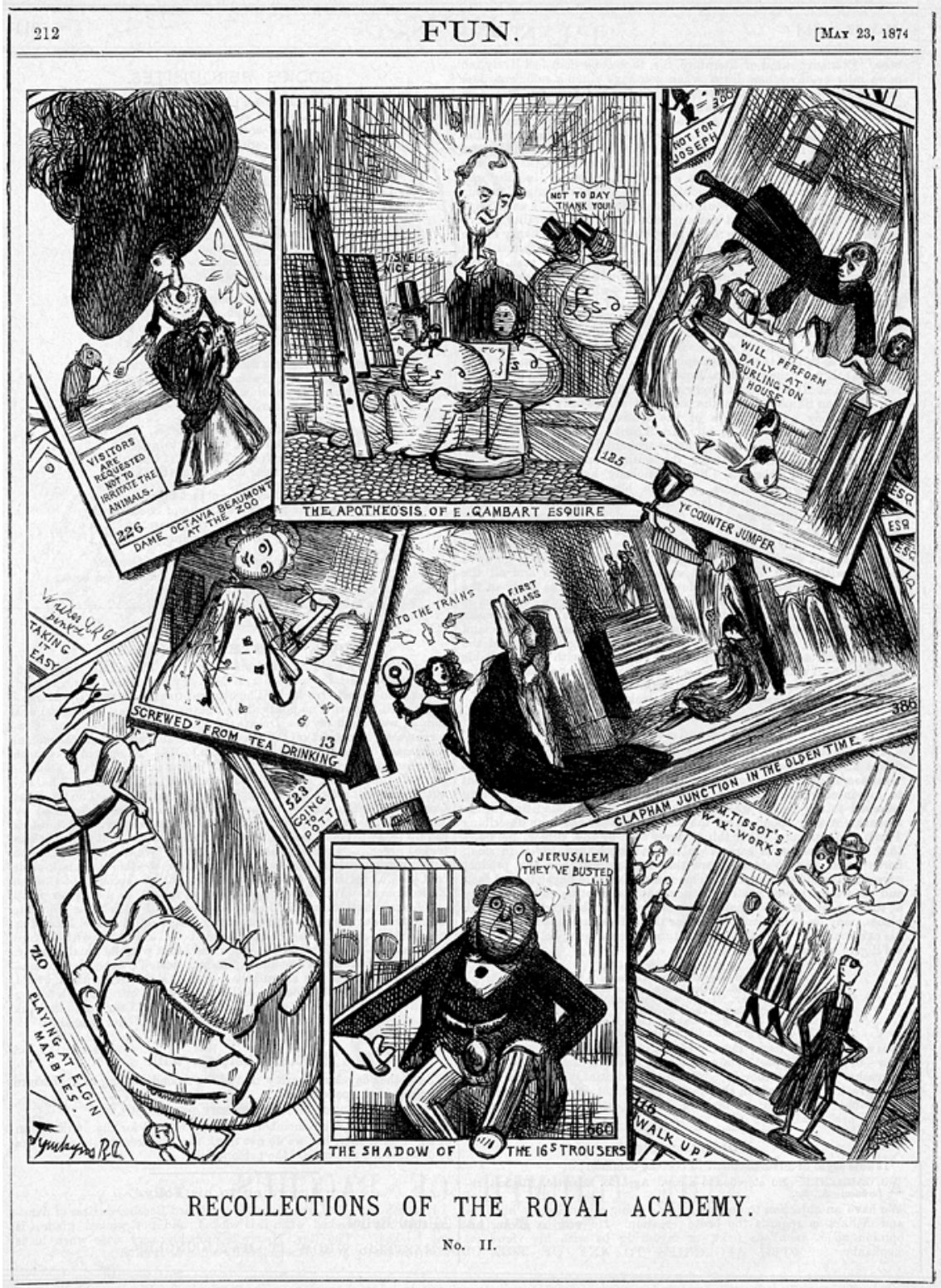

FIGURE 1.2 Anon., Recollections of the Royal Academy No. II, in Fun Magazine 26 (23 May 1874): 212

(C) COURTESY OF GEORGE A. SMATHERS LIBRARIES, UNIVERSITY OF FLORIDA 
these prints and the markets for which they were destined were radically international. Alma-Tadema engaged foreign engravers like Auguste Blanchard and Leopold Löwenstam for the reproduction of his paintings, and he was actively involved in the conquest of foreign markets for his prints. ${ }^{15}$

Alma-Tadema's painting seems to address this increasing international dimension of the trade in paintings and engravings. If the panels hanging in The Picture Gallery are meant to represent the lost Greek originals of the famous paintings that served as models for Pompeian mosaics and frescoes, then the scene as a whole may conjure the image of Roman plunder in its dominions, notably in antique Greek or Hellenist cities. ${ }^{16}$ As a depiction of a commercial gallery in ancient Rome rather than a pile of war spoils or a scene of plunder, however, the painting may refer first and above all to the (imagined) role of the Roman capital in the art market of classical antiquity. Rome is represented here as the uncontested centre of gravity of the art market, where art treasures from all corners of the vast Roman Empire constantly arrived, to be bought and sold by the wealthy and powerful Roman elite. In fact, the commercial transactions conducted around some of the works depicted in Alma-Tadema's painting are documented, and there is little doubt that Alma-Tadema was aware of this. For instance, the original full-length portrait of Medea hanging next to the doorway was bought for the price of forty talents by Julius Caesar, as described by Pliny the Elder in the Historia Naturalis, an important source for many of AlmaTadema's depictions of the Roman art world. ${ }^{17}$ Yet again, the scene should be related to, or translated into, Alma-Tadema's own time and the geographical context of Victorian London. By the second half of the nineteenth century, London was at the heart of another empire and was increasingly seen as the new Rome, performing the same role as the ancient city had, in a now even more connected and globalised world. As the capital of the world's leading industrial, commercial and military nation and, thus, the home of many vastly rich collectors, London was also quickly becoming artists' very own El Dorado, the most attractive commercial market for both old master pictures and contemporary art and as such the place where art treasures from all parts of the world were shipped in order to be bought and sold for huge sums of money.18

\footnotetext{
15 Robert Verhoogt, Art in Reproduction: Nineteenth-Century Prints after Lawrence AlmaTadema, Jozef Israëls and Ary Scheffer (Amsterdam: Amsterdam University Press, 2007), 427-506.

16 Becker et al., eds., Sir Lawrence Alma-Tadema, 189.

17 Swanson, The Biography and Catalogue Raisonné, 171.

18 Thomas M. Bayer and John R. Page, The Development of the Art Market in England: Money as Muse, 1730-19oo (London: Pickering \& Chatto, 2011), 99 ff; Petra ten-Doesschate Chu, "The Lu(c)re of London: French Artists and Art Dealers in the British Capital," in Monet's
} 
It is, indeed, not a coincidence that the caricature after The Picture Gallery represents the clients sitting and standing in the gallery as money bags.

Durand-Ruel's choice of the British capital was clearly the logical result of broader developments in the international art market. Further below, we will argue that the reference to German art in the name of his gallery, no matter how annoying, was part and parcel with these same developments. First, however, this chapter will further explore the gradual and dynamic process of the integration of local European art markets in the nineteenth century. After a brief sketch of the changing social, economic and technological contexts that made this process possible follows a broad overview of developments in the areas of distribution (exhibitions and dealers), production (artists) and consumption (collectors and other audiences). In the final section, we will then proceed to examine the prime importance of new modes of art knowledge structured along national categories in the internationalisation of the market, to which Durand-Ruel's accommodation in the German Gallery and his establishment of the Société des Artistes Français already hint.

\section{Commodification and Mobility}

Causes and consequences, means and effects, are difficult to disentangle in the rapid internationalisation of the nineteenth-century art market, considered in its broadest sense. At the most fundamental level, the changes in the art market were the result of the broader social and economic developments that were gradually restructuring society at large. This process created new audiences and new consumers for art and, in the long run, led to the growth and subsequent integration of national art markets (and markets in general). The new nineteenth-century public for art differed in many important ways

London: Artists' Reflections on the Thames 1859-1914 (Ghent: Snoeck, 2005), 39-54. See also: Jan Dirk Baetens, "The Belgian Brand: Ernest Gambart and the English Market for Nineteenth-Century Belgian Art, c. 1850-1870," Belgisch Tijdschrift voor Filologie en Geschiedenis—Revue Belge de Philologie et d'Histoire 92, no. 4 (2014): 1277-309; Pamela M. Fletcher, "Creating the French Gallery: Ernest Gambart and the Rise of the Commercial Art Gallery in Mid-Victorian London," Nineteenth-Century Art Worldwide 6, no. 1 (2007), http://www.19thc-artworldwide.org/springo7/46-springo7/springo7article/143-creatingthe-french-gallery-ernest-gambart-and-the-rise-of-the-commercial-art-gallery-in-midvictorian-london; Anne Helmreich, "The Goupil Gallery at the Intersection between London, Continent, and Empire," in The Rise of the Modern Art Market in London, 18501939, eds. Pamela Fletcher and Anne Helmreich (Manchester - New York: Manchester University Press, 2011), 65-84; Edward Morris, French Art in Nineteenth-Century Britain (New Haven - London: Yale University Press, 2005), esp. 127-6o. 
from the former elites that had patronised artists. While the speed and the specific dynamic of this evolution were surely different in countries throughout Europe, the general tendency was that the new consumer base increasingly came to consist of the middle classes-bankers, industrialists and people in trade or commerce who belonged to the bourgeois elite and started collecting art - and of a broader middle-class public that visited exhibitions and museums at home or abroad and consumed art in popular engravings, books and magazines. ${ }^{19}$

The expansion of the market induced by the rise of the bourgeoisie contributed to, and was facilitated by, firstly, an increased commodification of art and, secondly, a growing anonymisation of the market, where artists and collectors, even at the highest echelons, were rarely well acquainted with one another. The anonymisation of the market made it easier for artists to sell their work abroad through exhibitions and dealers and, conversely, for collectors to buy outside of their home markets. In addition, collectors belonging to this new class of clients frequently had some, or even extensive, professional experience in Europe's international markets. They often also supported free trade reforms. Their taste preferences contributed to the growing commodification of artistic goods and thus to their (international) exchangeability. The new

19 The process was, however, usually a gradual one and in many countries patronage by the state, the monarchy and the aristocracy continued to play a role. See for Belgium: Judith Ogonovszky, "Le Commerce de tableaux en Belgique sous la règne de Léopold Ier (1831-1865): première vue d'ensemble," Art \& fact 21 (2002): 9-11. Compare for France: Albert Boime, "Entrepreneurial Patronage in Nineteenth-Century France," in Enterprise and Entrepreneurs in Nineteenth- and Twentieth-Century France, eds. Edward C. Carter II, Robert Forster, and Joseph N. Moody (Baltimore - London: The John Hopkins University Press, 1976), 138-6o; Marie-Claude Chaudonneret, L'État et les artistes. De la restauration à la monarchie de Juillet (1815-1833) (Paris: Flammarion, 1999), 144-8; Marie-Claude Chaudonneret, "Collectionner l'art contemporain (1820-1840). L'exemple des banquiers," in Collections et marché de l'art en France 1789-1848, eds. Monica Preti-Hamard and Philippe Sénéchal (Rennes: Presses universitaires de Rennes, 2005), 273-82. See for England: Dianne Sachko Macleod, Art and the Victorian Middle Class: Money and the Making of Cultural Identity (Cambridge: Cambridge University Press, 1996). See for the Netherlands: Annemieke Hoogenboom, "Art for the Market: Contemporary Painting in the Netherlands in the First Half of the Nineteenth Century," Simiolus: Netherlands Quarterly for the History of Art 22, no. 3 (1993-94): 130; Id., De stand des kunstenaars. De positie van kunstschilders in de eerste helft van de negentiende eeuw (Leiden: Primavera, 1993), 131-7; Chris Stolwijk, Uit de schilderswereld. Nederlandse kunstschilders in de tweede helft van de negentiende eeuw (Leiden: Primavera, 1998), 157-60, 183-5 and 336-62; Richard Bionda, "De afzet van eigentijdse kunst in Nederland," in De schilders van Tachtig. Nederlandse schilderkunst 1880-1895, eds. Richard Bionda and Carel Blotkamp (Zwolle: Waanders, 1991), 62-7. See for Germany: Robin Lenman, Artists and Society in Germany 1850-1914 (Manchester - New York: Manchester University Press, 1997), 151-4. 
middle-class public, who were often denied the privileges of a traditional education and who were more modest in their aspirations or pretences than their aristocratic predecessors, usually gave preference to what Véronique ChagnonBurke has called 'peinture bourgeoise:' modestly sized and fairly effortlessly comprehensible still lifes, animal scenes, landscapes and genre scenes, all comparatively generic and interchangeable and therefore easy to ship, market and sell across borders. ${ }^{20}$ The commodification of art and anonymisation of market exchanges had already been anticipated in the seventeenth-century Netherlands and in eighteenth-century Paris, as is for instance clear from the dealings of Gersaint in Paris. Propelled by the rise to power of the new classes, however, these processes developed on a hitherto unseen scale in the course of the nineteenth century.

Once again, we can read this evolution towards an increased commodification and exchangeability of works of art in a bourgeois-dominated art economy in Alma-Tadema's The Picture Gallery. Examining the painting from a market-oriented perspective, Prettejohn's suggestion that the wooden panels and painted marble slabs we see in the gallery can be seen as representations of the lost originals of the mosaics and murals in Pompeii and Herculaneum may very well be reversed. ${ }^{21}$ Thinking the other way around, Alma-Tadema could be said not to "restore" the lost Greek originals after which the mosaics and frescoes in Southern Italy were modelled, but rather to commodify the works of art excavated in Pompeii and Herculaneum. By transforming these frescoes and mosaics into modestly sized panels or marble paintings, AlmaTadema makes them manageable, portable, transportable and hence more easily exchangeable and saleable. They become freely circulating commodities instead of fixed features in a patrician's house, in line with the bourgeoisification of the art market in the nineteenth century. ${ }^{22}$ It is striking, in this respect, that the clients visiting the gallery seem to ignore the two most famous works of art hanging on the walls: The Battle of Issus and The Sacrifice of Iphigenia. Both belong, in terms of subject matter, to the grand genre of history painting, which was quickly becoming obsolete in Alma-Tadema's time because of its limited commercial potential in a bourgeois-dominated art market. The other paintings in the room, by contrast, are entirely in line with bourgeois taste: two portraits above and next to the doorway, a seascape in the upper register

20 Véronique Chagnon-Burke, "Rue Laffitte: Looking at and Buying Contemporary Art in Mid-Nineteenth-Century Paris," Nineteenth-Century Art Worldwide 11, no. 2 (2012), http://www.19thc-artworldwide.org/summer12/veronique-chagnon-burke-looking-atand-buying-contemporary-art-in-mid-nineteenth-century-paris.

21 Becker et al., eds., Sir Lawrence Alma-Tadema, 186-9.

22 Bayer and Page, The Development, 175. 
next to it, a genre scene representing a theatre rehearsal and, finally, an animal piece depicting a lion in the lower register on the far right. It is to the latter painting, belonging to one of the lowest genres in the traditional genre hierarchy, that two of the visitors seem to direct all of their attention, as probably a large part of the new nineteenth-century audiences would do, to the desperation of more high-flown art critics. At least one critic seems to have caught Alma-Tadema's hint. He suggested in a discussion of The Picture Gallery that the lion was painted by the Edwin Landseer of Roman times, thus referring to the overwhelming popularity and commercial success that a mere animal painter like Landseer, one of the stars of the Victorian art scene, could have in a bourgeois-dominated art market. ${ }^{23}$

If the market's growth was the logical consequence of the increase of disposable income for the growing middle classes, the international dimension of its expansion was possible only because of an increased mobility of goods, persons and information, itself dependent again on evolving social, political, economic and technological developments that began in the eighteenth century. Central to this story was the eighteenth-century "transport revolution," which stimulated intra-European trade in general and thus encouraged exchange between national art markets, both primary and secondary. Dealers, collectors and connoisseurs were able to remain much more aware of movements in foreign markets than their seventeenth-century predecessors and they increasingly operated outside of their home markets. ${ }^{24}$ Improvements to roads and the transportation infrastructure further facilitated travel and export abroad. Information networks also tightened, as postal services became more efficient and were later complemented by commercial telegraphy, allowing easier and quicker communication across wide distances. Nineteenth-century newspapers and periodicals, on the rise as a result of improved printing processes and new commercial business models, could also reach audiences abroad and address foreign or international issues more efficiently. It was, again, the expanding middle classes that benefitted the most from easier and less expensive access to goods, travel and information, often across national borders. They visited museums and exhibitions at home and abroad, subscribed to national and foreign newspapers and periodicals, bought printed reproductions after old master paintings or contemporary masterpieces in national museums or

23 Becker et al., eds., Sir Lawrence Alma-Tadema, 188.

24 Dries Lyna, "Towards an Integrated Market? The Austrian Netherlands and the Western European Trade in Pre-Owned Paintings," in Moving Pictures: Intra-European Trade in Images, 16th-18th Centuries, eds. Neil De Marchi and Sophie Raux (Turnhout: Brepols, 2014), 277-88. 
foreign art collections and, at least in the upper strata of the bourgeoisie, collected paintings and other works of art with an often open, internationalist spirit.

The general trend towards an ever-increasing international mobility quickly affected art scenes across Europe, though it is sometimes difficult to gauge the exact speed of this process and the depth of its impact. The international circulation of printed reproductions was undoubtedly most important in quantitative terms. ${ }^{25}$ The success of firms like Goupil, Colnaghi and Buffa was founded on their print business, and, as Robert Verhoogt has shown, artists were sometimes just as involved in the reproduction of their work and the different markets of destination as they were in creating the original compositions. ${ }^{26}$ Prints were produced, published and distributed in international networks: a print after a Dutch painting could be engraved by a French artist, subsequently published by a British publisher and finally sold through a German retailer. International print dealers also worked their way around the national orientation of copyright legislation in order to cater to the growing interest in engravings as the nineteenth century progressed, as Verhoogt demonstrates in his contribution to this volume. The hugely popular illustrated press that developed in the first half of the century further boosted the international mobility of reproductions. Journals like L'Artiste, The Art-Journal and many others published prints after the work of foreign artists, sometimes also produced by foreign engravers or lithographers. Journals exchanged woodblocks or metal casts for printing with other journals from abroad. They were also often widely distributed throughout Europe and beyond, sometimes as far as the United States, Canada, Venezuela, Bermuda, Australia and even China. ${ }^{27}$

Figures on the import and export of art offer only broad estimates based on sources that are not always accurate or reliable, such as national trade statistics and customs records. ${ }^{28}$ The general impression conveyed by the available material, however, is that art other than prints circulated internationally in equally massive quantities, always — then as now-following

\footnotetext{
25 Verhoogt, Art in Reproduction, 213-23.

26 Id., passim.

27 Id., 223-40.
}

28 Custom duties would often be circumvented. See for instance: Agnès Penot, "The Perils and Perks of Trading Art Overseas: Goupil's New York Branch," Nineteenth-Century Art Worldwide 16, no. 1 (2017), http://www.19thc-artworldwide.org/index.php/spring17/penoton-the-perils-and-perks-of-trading-art-overseas-goupils-new-york-branch; María Isabel Baldassare, "Buenos Aires: An Art Metropolis in the Late Nineteenth Century," NineteenthCentury Art Worldwide 16, no. 1 (2017), http://www.19thc-artworldwide.org/index.php/ spring 17 /baldasarre-on-buenos-aires-an-art-metropolis-in-the-late-nineteenth-century. 
money. The example of the highly capitalised English market is probably the best known. In the late eighteenth and first two decades of the nineteenth centuries, about 20,000 European paintings were officially imported into England. ${ }^{29}$ A journalist of the Belgian journal La Renaissance wrote in 1849 that from Belgium alone no less than 2,238 had been shipped to England since $1833{ }^{30}$ Contemporaries, however, estimated that between 1825 and 1845 almost 300,000 old master pictures were imported into England from all over Europe. ${ }^{31}$ As the English market shifted over the course of the following decades, from a market aimed primarily at old master paintings to a market with a propensity for contemporary art, England also increasingly became the country of destination for modern painting from the Continent. ${ }^{32}$ Trade statistics show that in the second half of the century the import of art from a small country like Belgium often amounted to almost one million francs annually. ${ }^{33}$ Imports from countries like the Netherlands are likely to have been of similar importance, while those from France and the German states were probably much more significant. ${ }^{34}$

Although the art trade represented an almost negligible fraction of nations' economies or trade balances, governments deemed it sufficiently important to actively intervene in the international art market in order to further their national economic interests. In the early nineteenth century, for instance, some of the German states stimulated the use of the new medium of lithography in order to counter the British and French domination of the international print market. ${ }^{35}$ In the final decades of the century and the first decade of the twentieth century, German government officials also actively promoted the export of art to the United States, again against fierce French competition. ${ }^{36}$ At the

29 Guido Guerzoni, "The British Art Market 1789-1914," in Economic History and the Arts, ed. Michael North (Cologne: Bohlau, 1996), 97-132.

$30 \quad$ Anon., "Actualités," La Renaissance. Chronique des arts et de la littérature 11 (1849-50): 36.

31 Mark Westgarth, "Florid-looking Speculators in Art and Virtu': The London Picture Trade c. 1850," in The Rise of the Modern Art Market in London, 28.

32 Bayer and Page, The Development, $99 \mathrm{ff}$.

33 Anon., "Commerce de tableaux," Journal des Beaux-Arts et de la Littérature 3 (1861): 183; Baetens, "The Belgian Brand," 1293-7.

34 See for the Netherlands: Dieuwertje Dekkers, "Jozef Israëls, een succesvol schilder van het vissersgenre" (PhD diss., University of Amsterdam, 1994), 89-102. See for France: Edward Morris, French Art in Nineteenth-Century Britain.

35 Sophie Bobet-Mezzasalma, "Les galeries lithographiées: de la duchesse de Berry à Artaud de Montor," in Collections et marché de l'art en France 1789-1848, 409-11.

36 Lenman, Artists and Society in Germany, 158-61. 
same time, the French state attempted to conquer the budding Argentinean art market. ${ }^{37}$

\section{Distribution: Salons and Exhibitions}

The growing international mobility of art can be discerned most easily in the circuits of distribution that facilitated it, both the traditional circuits of annual Salons and other (semi-)official national (or regional) exhibitions and the unambiguously commercial circuits formed by networks of galleries that became increasingly dominant in the second half of the nineteenth century. Foreign artists certainly submitted work in increasing numbers to the prestigious annual Paris Salon, arguably the artistic (if not always commercial) epicentre of the European art world for most of the century. ${ }^{38}$ By 1845 , the presence of foreign art at the French Salon was so important that the organising committee drew up separate lists with the names of participating artists from abroad. ${ }^{39}$ Durand-Ruel observed in his memoirs that not all of these foreign artists were after direct sales in Paris: more important in their wish to exhibit in Paris was their awareness of the weight of the critical judgement of their work by the Paris art community. ${ }^{40}$ Artists counted on a successful passage in Paris, characterised by critical consecration or recognition in the form of official rewards, to constitute a firm basis for commercial success in their home markets or on the international scene at large. As mentioned in the introduction, foreign competition at the Paris Salons sped up the saturation of the Salon system and its ultimate incapacity to accommodate the careers of a steadily growing number of artists, which, in turn, created a space where dealers could seize power. ${ }^{41}$ This, however, only further stimulated the international distribution of works of art, as dealers often operated with a decidedly international perspective, easily buying and selling across borders. By the last decades of the nineteenth century, the influx of foreign artists and their competition for sales

37 Baldassare, "Buenos Aires."

38 See for instance: Tom Verschaffel, "Art and Nationality: The French Perception of Belgian Painters at the Paris Salons (1831-1865)," in Visions/Revisions: Essays on Nineteenth-Century French Culture, eds. Nigel Harkness et al. (Oxford - Bern - Berlin: Peter Lang, 2003), 126.

39 Id., 125.

40 Durand-Ruel, Memoirs, 31-2.

41 Harrison C. and Cynthia A. White, Canvases and Careers: Institutional Change in the French Painting World (Chicago - London: The University of Chicago Press, 1993); David W. Galenson and Robert Jensen, "Careers and Canvases: The Rise of the Market for Modern Art in Nineteenth-Century Paris," Van Gogh Studies 1 (2007): 137-66. 
and public rewards led to the final demise of the Salon itself and its replacement by a new type of radically internationalist exhibition. In 1890 a discussion over foreign participation in France resulted in the schism between the Société des Artistes Français and the Société Nationale des Beaux-Arts and, thus, to the co-existence of two rivalling Salons. ${ }^{42}$ The internationally oriented exhibition organised by the Sociéte Nationale proved the more successful of the pair and subsequently provided the model for the shows organised in the 1890 and 1900 s by the various secessionist movements all over Europe, all with an equally cosmopolitan outlook.

Contrary to what occurred in France, in England the Royal Academy remained mostly unsympathetic towards the participation of foreign artists in its annual summer exhibitions. ${ }^{43}$ This hostility, however, was precisely what allowed dealers like Gambart to develop their lucrative businesses based on the sale of contemporary art from abroad, often organising commercial shows on the fringes of the Royal Academy exhibition dedicated to specific national schools of painting. In other countries the relationship between the official exhibition circuit and the international art trade developed in still different ways. The Belgian prime minister Charles Rogier, for example, was always keen on using the arts to build an international reputation for the young Belgian nation. Clearly taking his cue from the Great Exhibition in London, in $185^{1}$ he ordered the annual Belgian Salon of contemporary art that was to take place in Brussels to be organised on a much grander and more international scale than before. ${ }^{44}$ Submissions from abroad, especially from France, were actively solicited, but because the organising committee lacked the logistical resources to realise these international ambitions, art dealers like Arthur Stevens, Gustave Coûteaux and François Petit were engaged to activate their networks and secure paintings by foreign artists. In the following years, the organising committees of the Salons in Antwerp and Ghent, which alternated with Brussels as guest cities for the national exhibitions, adopted the same practice and made

42 Robert Jensen, Marketing Modernism in Fin-de-Siècle Europe (Princeton: Princeton University Press, 1994), 154-63.

43 Morris, French Art in Nineteenth-Century Britain, 136-9.

44 Monique Nonne, "Artistieke wisselwerking: een paar voorbeelden," in Parijs-Brussel, Brussel_Parijs. Realisme, impressionisme, symbolisme, art nouveau. De artistieke dialoog tussen Frankrijk en België, 1848-1914, eds. Robert Hoozee and Anne Pingeot (Antwerp: Mercatorfonds, 1997), 42-3. See on Charles Rogier and the arts: Judith Ogonovszky, "Charles Rogier, mécène interposé d'un art national," in L'Argent des arts. La politique artistique des pouvoirs publics en Belgique de 1830 à 1940, eds. Ginette Kurgan-van Hentenryk and Valérie Montens (Brussels: Éditions de l'Université de Bruxelles, 2001), 63-71. 
use, for instance, of the services of the London-based agent Henry Mogford to attract paintings from Britain. ${ }^{45}$

The examples of the Belgian Salons are not exceptional. Exhibition organisers in provincial cities in France, Prussia and many other countries often had similar international ambitions and also regularly recruited the support of dealers to realise them. ${ }^{46}$ One striking aspect of this development, which testifies to the depth to which internationalism penetrated the very structure of the art world, is that international circuits were increasingly able to bypass national networks and hierarchies. France Nerlich has described, for instance, how Louis Sachse, a German art dealer who imported contemporary French painting for provincial exhibitions organised by local Kunstvereine, sometimes directly sourced from the studios of provincial French painters who had not yet been able to make a name for themselves in Paris. The result was that these painters could become well established abroad before having gone through the usual career stages in their home country (usually centred in its capital), thus defying, as it were, the internal geographic logic that normally determined artists' careers. ${ }^{47}$ The same prevalence of the international over the national can sometimes be seen on the level of exhibitions, against the internal geographical centre-periphery logic one would expect. Regional and local exhibitions in Germany, for instance, were at times more open to foreign art than the leading Berlin art world because of anti-French sentiment in the Prussian capital. ${ }^{48}$

Even more significant than the presence of foreign art at national or local exhibitions was the craze in the second half of the nineteenth century for expositions universelles, or world exhibitions, and the many, alas understudied, international exhibitions, sometimes dedicated specifically to the fine arts. ${ }^{49}$ Surprisingly, the commercial dimension of these exhibitions, and the machinations and intrigues behind them, have never received much attention. ${ }^{50}$ These

45 Baetens, "The Belgian Brand," 1307-8.

46 Nonne, "Artistieke wisselwerking," 51-52; France Nerlich, La Réception de la peinture française en Allemagne, 1815-1870 (Paris: Éditions de la maison des sciences de l'homme, 2009), 125-7 and 171-2.

47 France Nerlich, "La fin de l'exclusion artistique. Le marchand d'art berlinois Louis Friedrich Sachse à la conquête de la province," in Marché(s) de l'art en province 18701914, eds. Laurent Houssais and Marion Lagrange (Bordeaux: Presses universitaires de Bordeaux, 2010), 145-7.

48 Id., $150-4$.

49 Jensen, Marketing Modernism, 163. See however: Martha Filipová, ed., Cultures of International Exhibitions 1840-1940: Great Exhibitions in the Margins (London - New York: Routledge, 2015).

50 Jan Dirk Baetens, "The General Exhibition of Pictures of 1851: National Schools and International Trade in the Mid-Victorian Art Market," Visual Culture in Britain 17, no. 3 (2016), 270-89. 
prestigious exhibitions functioned as international showcases of art and could, besides establishing or endorsing an artist's reputation in his home country, launch international careers. Again, art dealers, always happy to rub up with government officials, were usually eager to be involved and to make use of the commercial possibilities created by these shows. Durand-Ruel, for instance, took charge of the French section of the international exhibition organised in London in 1871 and quickly responded affirmatively to the French government's request to send in works for the international exhibition in Vienna in $1873 .{ }^{51} \mathrm{He}$ also seized the commercial opportunity presented to him by his involvement in the Vienna exhibition to organise his own commercial exhibition of the 'fine French school' on the fringes of the official programme. The Dutch section at the 1893 World's Columbian Exhibition in Chicago was almost entirely an affair of the Dutch dealer Abraham Preyer, who acted as general manager for the Dutch submissions and joined forces with the internationally operating Goupil dealership for the occasion. ${ }^{52}$ Following the Columbian Exhibition, Preyer organised an auction of the unsold works, supplemented by fresh arrivals from the Netherlands, and a year later he opened the so-called Holland Art Galleries in New York. The influence of dealers was also felt in the press coverage surrounding these international events and even in the distribution of medals and other honours to the participating artists. The great medal of honour that the Belgian painter Henri Leys received at the first $e x$ position universelle in Paris in 1855 seems to have been the happy outcome (for him at least) of the machinations of his dealer, Gustave Coûteaux. Apparently, the latter had outsmarted the rivalling Belgian dealer Arthur Stevens, who was promoting his brother Alfred's interests, if we are to believe Leys's letters. ${ }^{53}$

\section{Distribution Continued: Travelling Picture Pedlars and Art Multinationals}

It is not surprising that dealers were so often involved in official or statesponsored exhibitions with international ambitions. Many of them conducted their business in the full understanding, and use, of the growing international potential of the market. The trade in old master paintings had been an international affair since at least the sixteenth century. This evolution, however,

$5^{1} \quad$ Durand-Ruel, Memoirs, 80 and 107-8.

$5^{2}$ Dekkers, Jozef Israëls, 116; Id., "Where Are the Dutchmen?' Promoting the Hague School in America, 1875-1900," Simiolus: Netherlands Quarterly for the History of Art 24, no. 1 (1996): $67-8$.

53 Jan Dirk Baetens, "Vanguard Economics, Rearguard Art: Gustave Coûteaux and the Modernist Myth of the Dealer-Critic System," Oxford Art Journal 33, no. 1 (2010): 38. 
reached its climax in the nineteenth century. By 1867 the French critic Philippe Burty noted that 'almost all important deals in old master paintings [were] arranged by a handful of prominent agents, travelling from France to England, from Spain to Russia, thus keeping in touch with the desires of rich amateurs and the lacunas in museums. ${ }^{54}$ Eighteenth-century and early nineteenthcentury dealers in contemporary art also increasingly targeted foreign markets with their wares. When John Boydell planned his famous Shakespeare Gallery in the 1780s, he had both the British and the French markets in mind, only to be frustrated in his ambitions by the French Revolution and the Napoleonic Wars. ${ }^{55}$ After the wars, in the 1820 s, John Arrowsmith applied himself to the import of contemporary British pictures into France, including, famously, a number of paintings by John Constable. ${ }^{56}$ French sensation pictures were, conversely, regularly exhibited in Britain, where they were used to promote the sale of engravings after them, either on artists' own accord or with the support of entrepreneurs such as the exhibition organiser William Bullock. ${ }^{57}$

In the following decades, the international scope of dealers' business schemes only became more prevalent. Many dealers in contemporary art started to specialise in the export and/or import of specific national schools to other markets. Gambart made his career in London first and above all with the promotion of French and, to a lesser extent, Belgian, Dutch and German art. Durand-Ruel only arrived at establishing the modern French school of impressionist painting when he succeeded in selling the impressionists' work abroad. His main Paris competitor, Georges Petit, mirrored this strategy and organised a series of exhibitions of the work of prominent foreign artists in his luxurious Paris gallery, ostensibly under the aegis of the so-called Société Internationale de Peinture, again a label that referred to the benefits of exchange between national schools. ${ }^{58}$ Earlier, Georges Petit's father, François, had already put together some of the collections of prominent amateurs in the Netherlands and Russia. ${ }^{59}$ The Belgian dealer Arthur Stevens, who operated in Paris for

54 Philippe Burty, "L'hôtel des ventes et le commerce de tableaux," in Paris-Guide. Par les principaux écrivains et artistes de la France, vol. 2 (Paris: Librairie internationale, 1867), 960.

55 Rosie Dias, Exhibiting Englishness: John Boydell's Shakespeare Gallery and the Formation of a National Aesthetic (New Haven - London: Yale University Press, 2013), 65-125 and $217 \mathrm{ff}$.

$5^{6}$ Linda Whiteley, "Art et commerce d'art en France avant l'époque impressionniste," Romantisme 13 (1983): 69-71.

57 Oskar Bätschmann, The Artist in the Modern World: The Conflict between Market and Self-Expression (Cologne: DuMont, 1997), 44-52.

58 Jensen, Marketing Modernism, 63-7.

59 Burty, "L'hôtel des ventes," 962. 
much of his career, promoted modern French art, mostly Barbizon painting, in Belgium, Russia and other European countries. ${ }^{60}$ German dealers like Louis Sachse specialised in the import of French art. ${ }^{61}$ The Lepke dealership imported contemporary French art in the German territories, but at the same time it also introduced the Parisian auction culture to Berlin, as Lukas Fuchsgruber convincingly shows in his chapter in this volume.

The second half of the nineteenth century also saw the rise of actual multinationals in the art world. Goupil \& Cie (later renamed Boussod, Valadon \& Cie), arguably the most successful dealership of the nineteenth century, had branches in Paris, London, The Hague, Brussels, Berlin and New York (the latter was taken over by Michael Knoedler in 1857 and continued under his name, becoming one of the most successful art dealerships in the US).${ }^{62}$ It was also connected to an extensive network of other dealers, many of whom had learned the trade in one of the Goupil branches. ${ }^{63}$ Others, including the Scottish dealer Daniel Cottier, Arthur Tooth from London, Agnew's from Manchester and the Dutch firm E.J. van Wisselingh \& Co., followed suit and established branches in cities in Europe and the United States. ${ }^{64}$ The advantages of such an international corporate structure were clear: it created the possibility of a larger stock that was distributed and sometimes circulated amongst several retail spaces or auctioned off in different cities, it allowed for the spread of business risks over an entire network and thus for the absorption of the effects of political and economic difficulties in specific national markets, and it could build on the shared expertise and personal networks of a large number of employees following up on artistic and commercial developments in different national art scenes. ${ }^{65}$

6o Gustave Vanzype, Les frères Stevens (Brussels: Nouvelle société d'éditions, 1936), 80-91; Robert Hoozee, "Barbizon en België," in De school van Barbizon. Franse meesters van de 19de eeuw, eds. John Sillevis and Hans Kraan (Ghent: Museum of Fine Arts, 1985), $116 \mathrm{ff}$; Boris I. Asvarisch, "Les artistes belges et leurs peintures: le point de vue de la Russie," in Peintures belges de l'Ermitage, ed. Boris I. Asvarisch (Venice: Marsilio, 1999), 27-34.

61 France Nerlich, La Réception de la peinture française, 103-24, 140-2, 175-6 and 239-49; Anna Ahrens, Der Pionier. Wie Louis Sachse in Berlin den Kunstmarkt erfand (Cologne Weimar - Vienna: Böhlau, 2017).

62 Gérôme \& Goupil: Art and Enterprise (Paris: Réunion des musées nationaux, 2001); Anne Helmreich, "The Art Dealer and Taste: The Case of David Croal Thomson and the Goupil Gallery, 1885-1897," Visual Culture in Britain 6, no. 2 (2005): 31-49; Id., "The Goupil Gallery," 65-84; Penot, "The Perils and Perks."

63 Penot, La Maison Goupil, 350-1.

64 Helmreich, "The Goupil Gallery," 68.

65 Id., 74; Richard Thomson, "Theo van Gogh: An Honest Broker," in Theo van Gogh 1857-1891: Art Dealer, Collector and Brother of Vincent, eds. Chris Stolwijk and Richard Thomson (Zwolle: Waanders, 1999), 81; Penot, La Maison Goupil, 248-53 and 274. 
Even dealers operating on a more limited scale or in the low end of the market often adopted a similar international approach. They travelled through Europe with a small stock of paintings to be shown in hotels or other modest exhibition sites, acted as occasional middlemen in international networks, or sometimes dealt in large quantities of inexpensive, mass-produced prints and pictures. In the 1840 os and 1850 s, before the firm's great breakthrough, DurandRuel senior and junior regularly toured Europe with their stock. ${ }^{66}$ Hardly anything is known, however, about the Belgian dealers Albert D'Huyvetter senior and junior, who shipped thousands of contemporary Belgian paintings to America-mostly smallish, inexpensive and repetitive traditionalist pictures - and were later even held responsible for provoking the decline of a large part of the Belgian school with their mass exports. ${ }^{67}$

It is striking in this respect, if not surprising in the light of the unprecedented mobility of both goods and persons, that many art dealers, again operating in all strata of the market, were migrants or descendants of foreign stock. ${ }^{68}$ Both Arthur Stevens and Adolphe Coûteaux, two of the most active dealers in and promotors of the Barbizon school in Paris, were Belgian. ${ }^{69}$ Joseph-Henry Rittner, who founded what would become Goupil \& Cie in 1827, was a German immigrant. Charles Sedelmeyer, who conquered the Paris art market (and then the US) a few decades later, was of modest Austrian origins, while the German Daniel-Henry Kahnweiler rose to prominence in Paris in the first decade of the twentieth century. ${ }^{70}$ Gambart, the 'prince of the Victorian art world,' had migrated from Belgium, while the Colnaghi dealership, also in London, was established by Italian migrants. ${ }^{71}$ These renowned dealers operated within intricate migrant communities, fostering ties with their native countries while at the same time forging new alliances in their new places of residence. In her

66 Durand-Ruel, Memoirs, 11 and 24.

67 Anon., "Art et mercantilisme," L'Art moderne 20 (1900): 89; Frank Van Den Wijngaert, "De schilderkunst in de XIXde eeuw," in Bouwstoffen voor de geschiedenis van Antwerpen in de XIXde eeuw. Instellingen - economie - kultuur (Antwerp: Lloyd Anversois, 1964), 329-30.

68 Christian Huemer, "Crossing Thresholds: The Hybrid Identity of Late NineteenthCentury Art Dealers," in Crossing Cultures: Conflict, Migration and Convergence, ed. Jaynie Anderson (Melbourne: Miegunyah Press, 2009), 1007-11.

69 See on Adolphe Coûteaux: Baetens, "Vanguard Economics," 30; Pierre Miquel, Le Paysage français au XIX ${ }^{e}$ siècle 1824-1874. L'école de la nature (Martinelle: Maurs-la-Jolie, 1975), passim.

$70 \quad$ Huemer, "Crossing Thresholds," 1007-11; Jeanne-Bathilde Lacourt, ed., Picasso, Léger, Masson: Daniel-Henry Kahnweiler et ses peintres (Villeneuve-d'Ascq: LaM, 2013).

71 See on Colnaghi's: Tim Warner-Johnson and Jeremy Howard, Colnaghi: Past, Present and Future. An Anthology (London: Colnaghi, 2016). 
contribution to this book, Camilla Murgia unravels the Italian artistic community in London at the end of the eighteenth century. Migrant communities sometimes also formed actual international networks across Europe to accommodate their trade. Members of the twelve-odd families that made up the population of the tiny North Italian mountain village Pieve Tesino, including the Tessaro, Caramelli and Buffa families, travelled as print pedlars through Europe from the eighteenth century onwards, regularly restocking through local contacts and sometimes only returning home after years of travel. Some of them subsequently settled in cities like Amsterdam, Antwerp, Koblenz and even Moscow and established permanent premises, including the prestigious Buffa dealership in Amsterdam, while usually also remaining in touch with their local and family networks. ${ }^{72}$

Dealers also developed new strategies to conquer foreign markets. DurandRuel and Gambart organised special exhibitions abroad to market their artists. Gambart and others also set up international tours of highly publicised and eye-catching paintings, usually with a range of printed reproductions or photographs on offer during the show. ${ }^{73}$ On a more modest scale, Theo van Gogh could send a 'mixed bag' of modern French art abroad simply to test the market. ${ }^{74}$ Some of these strategies were developed in direct response to the new logistic and financial challenges created by the internationalisation of the market. Notably transportation, though more efficient than in previous times, was still costly and entailed risks, and insurance and custom duties could seriously reduce profit margins. ${ }^{75}$ Thus, in the late 1840 os Goupil set up the International Art Union in New York, both to promote their stock of prints and to circumvent custom duties on paintings that were now purportedly imported for non-commercial reasons, namely because they would be shown in the exhibitions organised under the umbrella of the allegedly philanthropic Art Union. ${ }^{76}$ The firm's later decision to publish a number of promotional albums with works of art for sale for the American market was informed by the high cost involved in the transportation of the actual paintings across the Atlantic

72 Sylvia Alting van Geusau, "Kunst aan de Kalverstraat. De handelszin van Frans Buffa \& Zonen," in Kunsthandel Frans Buffa \& Zonen 1790-1950, eds. Sylvia Alting van Geusau, Mayken Jonkman, and Aukje Vergeest (Zwolle: Waanders, 2016), 37-44.

73 See for a wonderfully detailed case study: Jeremy Maas, Holman Hunt and the Light of the World (Aldershot: Wildwood House, 1984).

74 Thomson, "Theo van Gogh," 81.

75 Penot, La Maison Goupil, 227-34.

76 Penot, "The Perils and Perks." 
without the guarantee of sales. ${ }^{77}$ The development in earlier decades of other strategies, like the formation of buying syndicates and the use of private sale contracts, which both proved their value in the context of the famous Orléans sale, was also impacted by the internationalisation of the market. ${ }^{78}$

\section{Supply: Artists in an International Environment}

Dealers sometimes stimulated artists to adapt their production to foreign markets. In the late 186os, for instance, the promising Dutch artist Frederik Hendrik Kaemmerer largely abandoned landscape painting in his native Dutch tradition and started painting typically French diréctoire scenes under the impulse of Goupil \& Cie, which had paid for his training in the studio of Jean-Léon Gérôme and also became the young artist's main commercial outlet. ${ }^{79}$ The perspective of artists, however, was as international as that of dealers: many artists studied abroad and often travelled to different countries to visit museums or exhibitions, or simply to sketch or paint. Artists often also wanted to conquer foreign markets as eagerly as dealers and usually readily collaborated with dealers for this purpose. They sometimes developed or adapted their artistic productions according to the exigencies of foreign markets, but the result of such strategies could go in different directions. The Belgian artist Victor-Jules Génisson made a number of paintings of English church interiors clearly destined for the British market and constantly tried to gauge British taste in his correspondence with his London contact. In his letters, he confessed that he aimed at a share of the London art market, the financial resources of which he thought were inexhaustible. Even if it was true, he wrote in a letter from 1851, that in the person of David Roberts Britain already had a specialist in historic interiors, there would be plenty left for him: 'where he [Roberts] has

77 DeCourcy E. McIntosh, "Goupil's Album: Marketing Salon Painting in the Late Nineteenth Century," in Twenty-First-Century Perspectives on Nineteenth-Century Art: Essays in Honor of Gabriel P. Weisberg, eds. Petra ten-Doesschate-Chu and Laurinda S. Dixon (Newark: University of Delaware Press, 2008), 77-84.

78 See on the Orléans syndicate: Inge Reist, "The Fate of the Palais Royal Collection: 1791-1800," in La Circulation des oeuvres d'art-The Circulation of Works of Art in the Revolutionary Era, 1789-1848, eds. Roberta Panzanelli and Monica Preti-Hamard (Rennes: Presses universitaires de Rennes, 2007), esp. $30 \mathrm{ff}$. See on the use of private contract sales: Julia Armstrong-Totten, "Expand the Audience, Increase the Profits: Motivations Behind the Private Contract Sale," in Id., 45-55.

79 Mayken Jonkman, "Frederik Hendrik Kaemmerer. De lieveling van de kunstmarkt," in Nederlanders in Parijs 1789-1914, ed. Mayken Jonkman (Bussum: Thoth, 2017), 131-47. 
harvested richly, I am happy to glean in his footsteps. ${ }^{\prime 80}$ Gustave Courbet tried to serve several national markets and varied his output of landscape paintings in accordance with differences in taste between French, German, British and other collectors, which he also described in his instructions to his various commercial agents. ${ }^{81}$ Other artists adapted their marketing technique according to local circumstances: the Italian sculptor Medardo Rosso, for example, held live casting parties with champagne in Paris, managed to get included in the landmark Vienna Secession of 1903 and donated his own pieces of sculpture to a museum in Dresden alongside sold copies of ancient sculpture, as Sharon Hecker describes in her contribution to this volume.

Artists could, however, also reason the other way around. The success abroad of a certain "style" or type of work that was deemed typical of a specific national school, or sometimes even promoted as an actual national "brand," could also encourage artists to emphasise the perceived national distinctiveness of their work rather than suppress or adapt it. Foreign markets could thus not only animate other artistic scenes, but they could also stimulate the development of distinctly national or regional schools of painting in other countries (or groups of painters that were seen as such). This was, for instance, the case for the Hague school, which was able to grow and prosper thanks to its popularity in England, Scotland and America, where its output was considered as quintessentially Dutch..$^{82}$ The process of national branding that could accompany mass exports to foreign markets could also lead to artistic sclerosis. Most of the artists of the now largely forgotten school of Écouen in France, for instance, ended up in endlessly repeating traditional artistic recipes in mass-produced French genre paintings, virtually all of which were destined for the American market. ${ }^{83}$ Finally, artists could also try to balance the appeal of distinct national characteristics in their art with foreign preferences in taste. Some of the features of Claude Monet's landscape paintings of the 1880 s have been explained in this way. They show the distinctive appeal of French nature but leave out the potentially disturbing presence of French people, with their

\footnotetext{
$80 \quad$ Baetens, "The Belgian Brand," 1281 and 1303.

81 Petra ten-Doesschate-Chu, The Most Arrogant Man in France: Gustave Courbet and the Nineteenth-Century Media Culture (Princeton: Princeton University Press, 2007), $148 \mathrm{ff}$.

82 Dekkers, Jozef Israëls, 132-50; Id., "Where Are the Dutchmen?," 54-73; Frances Fowles, Van Gogh's Twin: The Scottish Art Dealer Alexander Reid 1854-1928 (Edinburgh: National Galleries of Scotland, 2010), $15 \mathrm{ff}$.

83 Michaël Vottero, La Peinture de genre en France, après 1850 (Rennes: Presses universitaires de Rennes, 2012), 354-8.
} 
social or political implications: a perfect recipe for foreign collectors who were attracted to the French landscape but 'wanted their France as pure "art."'84

The import and export of art could also affect national or local art scenes in many other ways, both artistically and outside of the immediate artistic realm. It could stimulate institutional developments, as it did in the Netherlands, where the international trade led to a (comparatively late) professionalisation of the local art market. ${ }^{85}$ In the United States, a negative, protectionist response to imports from Europe led to the foundation of the American ArtUnion and other initiatives to encourage American artists. ${ }^{86}$ Exports, especially of old master paintings and antiquities, could also stir up nationalist reflexes and stimulate initiatives to protect national heritage or provoke acquisitions by the budding national or local museums. ${ }^{87}$ The easy accessibility of foreign art could also elicit artistic responses from local artists. The introduction of Constable in France by the dealer John Arrowsmith had a clear effect on the development of Barbizon landscape painting. ${ }^{88}$ The Scottish art dealer Alexander Reid played a more active role. He introduced local artists George Henry and Edward Atkinson Hornel, whose work he promoted, to Japanese prints and even sent them on a fully financed study trip to Japan in order to stimulate the japoniste tendencies in their art. ${ }^{89}$ In London around 1900 the successful import of modern French art alongside a thriving market for Spanish, Dutch and Italian old master paintings allowed British artists to create their own cosmopolitan visual language, as Barbara Pezzini shows in her chapter in this book.

\section{Demand: International Collectors and National Tastes}

The import of art from abroad was intricately intertwined with evolving taste patterns and thus with the formation of art collections. The increasing international mobility of art in the nineteenth century clearly played a major

\footnotetext{
84 Thomson, "Theo van Gogh," 116.

85 Stolwijk, Uit de schilderswereld, 26.

86 Craig Houser, "Disharmony and Discontent: Reviving the American Art-Union and the Market for United States Art in the Gilded Age," Nineteenth-Century Art Worldwide 11, no. 2 (2012), http://www.19thc-artworldwide.org/summer12/craig-houserdisharmony-and-discontent.

87 Benjamin Péronnet, "La presse et le marché de l'art, de la Révolution à la Restauration," in Collections et marché de l'art en France 1789-1848, 102.

88 Linda Whiteley, "Art et commerce d'art en France avant l'époque impressionniste," Romantisme 13 (1983): 69-71.

89 Fowles, Van Gogh's Twin, $62 \mathrm{ff}$.
} 
part in collecting practices. In some cases, like that of the sale of the Orléans collection in Britain, the presence of imported art affected local taste. ${ }^{90}$ Throughout the nineteenth century, French Ancien Régime furniture continued to play a significant role in British interiors. English aristocrats appropriated the art of their (former) enemy by assigning both English and international signification to it, as Adriana Turpin's contribution to this volume demonstrates.

The example of the Orléans sale illustrates that the art market internationalised partly in response to the opportunities created by the uneven distribution amongst cities, regions and countries of (bourgeois, aristocratic or other) buying potential. Both old master and contemporary art "followed the money:" to London during most of the nineteenth century, to the United States in the final decades of the century, but also to more unexpected locations like Buenos Aires, targeted by European dealers because of the rising purchase power of the wealthy bourgeoisie at the end of the century. ${ }^{91} \mathrm{~A}$ disequilibrium between local demand and local supply further stimulated artists or dealers to export in the face of such weak local demand or motivated collectors to make purchases abroad because of limited local supply possibilities (and the high prices this would entail). Contemporary foreign art was, however, even imported in Paris, arguably the most prolific art production centre of the time. ${ }^{92}$ This suggests that foreign markets not only originated from a surplus in wealth and demand in face of a weak supply, but they were also created by artists and dealers promoting certain artists or schools from abroad.

It is difficult to determine whether the changes in collectors' taste preferences were influenced by international trade or were, conversely, what invited this trade in the first place. Changes in the supply side may have sometimes played a greater role in the market for old master paintings. It is well known that confiscations and plunder during the revolutionary era in France and during the Napoleonic Wars that raged throughout Europe in the following decade brought huge quantities of old master pictures to the market. ${ }^{93}$ Aristocratic collections and works of art in the possession of religious institutions were sold or exported and officers from Napoleon's army built important collections

90 Reist, "The Fate of the Palais Royal Collection," 34.

91 Ten-Doesschate-Chu, "The Lu(c)re of London," 39-54; Madeleine Fidell-Beaufort and Jeanne K. Welcher, "Some Views of Art Buying in New York in the 1870s and 188os," Oxford Art Journal 5, no. 1 (1982): 48-55; Baldassare, "Buenos Aires."

92 See for instance Thomson, "Theo van Gogh," 81.

93 See some of the essays, esp. those related to the Orléans sale, in: Panzanelli and PretiHamard, eds., La Circulation des ouvres d'art. 
of foreign art and antiquities. ${ }^{94}$ After (and sometimes even during) the wars, powerful dealers like John Smith and his main competitors, Lambert-Jean Nieuwenhuys and his son Chrétien, roamed the Continent and shipped thousands of paintings to England. ${ }^{95}$ It may very well be that dealers like father and son Nieuwenhuys and Smith, responding to the changes on the supply side of the market, could sometimes weigh on collecting patterns. In the first decades of the nineteenth century, many significant late medieval Netherlandish paintings, most of them looted, confiscated or bought from religious institutions, were in the hands of dealers, with only a moderate interest in them from the demand side. ${ }^{96}$ Subsequently, however, collectors and museums gradually started buying Flemish primitives, often directly from Nieuwenhuys, Smith and their peers. The availability of these works and their active promotion by dealers may very well have influenced this new taste, together with the rise in scholarly interest in these paintings.

Changes on the demand side, however, also contributed to the momentum of the market for old master painting in the first decades of the nineteenth century. The advent of new collectors, eager to acquire works freshly arrived on the market, was one element. The establishment of national museums in countries all over Europe was another. Virtually all of them aimed to secure a representative collection of national art following the return of collections looted by Napoleon and the concomitant surge in nationalist sentiments, while the most ambitious of these new museums even aspired to become 'universal survey museums,' with representative samples of art from all national

94 See for instance: Véronique Gerard-Powell, "Les collections des officiers de l'armée impériale pendant la campagne d'Espagne: un butin très varié," in Collections et marché de l'art en France 1789-1848, 305-17; Patricia A. Teter, "English Gold, Corsican Brass, and French Iron': Opportunities for Collecting Art in Spain During the Napoleonic Wars," in La Circulation des æeuvres d'art, 309-21.

95 Gerald Reitlinger, The Economics of Taste: The Rise and Fall of Picture Prices 1760-1960, vol. 1 (New York: Hacker Art Books, 1982), 26-56; Bayer and Page, The Development, 89-98; Charles Sebag-Montefiore and Julia I. Armstrong-Totten, A Dynasty of Dealers: John Smith and his Successors, 1801-1924 (London: The Roxburghe Club, 2013). The Nieuwenhuys dealership remains, alas, unstudied. See for some basic information: Erik Hinterding and Femy Horsch, "A Small but Choice Collection': The Art Gallery of King Willem II of the Netherlands (1792-1849)," Simiolus: Netherlands Quarterly for the History of Art 19, no. 1-2 (1989): esp. 9.

96 Till-Holger Borchert, "De geschiedenis van het verzamelen van de Oudnederlandse schilderkunst in de negentiende eeuw," in 'Om iets te weten van de oude meesters.' De Vlaamse Primitieven-herontdekking, waardering en onderzoek, eds. Bernhard Ridderbos and Henk van Veen (Amsterdam: Sun, 2005), 140-88. 
schools. ${ }^{97}$ To what extent supply followed demand, or vice versa, then, is difficult to say: the history of taste always remains elusive.

A substantial number of high profile collectors was also serviced by an increasingly international supply chain. They not only regularly bought old master paintings from foreign schools, but they also often purchased contemporary work from foreign artists and sometimes even built representative collections of specific national schools or local schools from abroad. The Belgian collectors Prosper Crabbe and Jules van Praet both owned prestigious collections of French Barbizon paintings, including masterpieces such as Jean-François Millet's famous Angelus. ${ }^{98}$ Early Russian collectors like Nikolai Borisovich Yusupov specialised in French art, while his contemporary Alexander Sergeyevich Stroganov focused on Italian art. ${ }^{99}$ Later Russian amateurs followed the same pattern. Nicolai Kosjolev-Bezborodko, for instance, collected French art, while Alexander Gorchakov had a special interest in contemporary Belgian art. ${ }^{100}$ American collectors of the last decades of the nineteenth century increasingly surpassed all others in their acquisitions. In 1857 the Belgian art critic Emile Leclercq wrote that many of the best Belgian paintings were exported to Russia, while copies and bad and mediocre paintings were put on a boat to America. ${ }^{101}$ In the 188 os, however, journalists boasted that the Americans owned more French masterpieces than France itself, often Barbizon pictures and popular Salon paintings. ${ }^{102}$ In the following years, America would also become the main market for impressionist and old master paintings. ${ }^{103}$ This influx of European paintings in the American market allowed New York intermediaries to educate auction and exhibition visitors via

97 Bénédicte Savoy, "Conquêtes et consécrations. Paris-Berlin 1815," in La Circulation des ouvres d'art, 85-97. See on the 'universal survey museum:' Carol Duncan and Allan Wallach, "The Universal Survey Museum," Art History 3, no. 4 (1980): 448-69.

98 Hoozee, "Barbizon en België," 114-8.

99 Elena Sharnova, "Un vrai musée de la peinture française': la collection française de Nicolaï Borissovitch Youssopov," in Collections et marché de l'art en France 1789-1848, 359-73; Susanne Jaeger, Alexander S. Stroganov (1733-1811). Kunstsammler und Mäzen im Russland der Aufklärung (Cologne: Böhlau, 2007).

100 Boris Asvarisjtsj, "De galerie van vorst Aleksandr Gortsjakov" and "De galerij van KoesjelevBezborodko," in Verzamelaars in Sint-Petersburg (Zwolle: Waanders, 2007), 66-81 and 82-97.

101 E. Pittore [Emile Leclercq], "Collections particulières d'objets d'art. Galerie de M. Van Becelaere," Uylenspiegel. Journal des ébats artistiques et littéraires 2, no. 6 (1857-58): 1.

102 Madeleine Fidell-Beaufort, "The American Art Trade and French Painting at the End of the 19th Century," Van Gogh Museum Journal 6 (2000): 105. See also: Lois Marie Fink, "French Art in the United States, 1850-1870: Three Dealers and Collectors," Gazette des Beaux-Arts 120 (1978): 92-9.

103 Thompson, "Paul Durand-Ruel," 106-19. 
catalogues and boost their own cultural and social capital, as Leanne Zalewski shows in her chapter in this book.

Collectors could source from local branches of international firms like Goupil.104 They sometimes also actively monitored foreign supply markets, sent agents abroad or enlisted the help of local middlemen like George A. Lucas, who bought in Paris for some of the most acquisitive American collectors of contemporary art. ${ }^{105}$ Of course collectors also travelled abroad themselves. Indeed, the history of collecting has always been connected to the history of travel: ambassadors, foreign princes and army officers of conquering armies have always been prominent amongst collectors. ${ }^{106}$ The mobility of collectors increased, however, as larger groups of people obtained the financial means for travel, which also became easier and cheaper in itself. In the last decades of the nineteenth century, for instance, many of the wealthy art-buying bourgeoisie of Buenos Aires regularly made the voyage to Paris to buy the latest fashionable clothes, furniture and art for their houses. ${ }^{107}$

Local artists and dealers were well aware of the presence of collectors from abroad. Durand-Ruel wrote in his memoirs that he would have preferred a location for his gallery on the boulevard Montmartre over his address in the rue Lafitte, not only because a lot of wealthy Parisians passed through the boulevard Montmartre, but also because foreigners often strolled there. ${ }^{108}$ Foreign collectors also visited local exhibitions, if we are to believe the comments in the press. In 1849, for instance, a Belgian art critic noted in his review of the tri-annual Antwerp Salon with some relief that, in spite of the recent political upheavals in Europe (the wave of revolutions in 1848), the interest of foreign amateurs in the Salon had not diminished. ${ }^{109}$ Tourism was undoubtedly an important force behind these collecting patterns. In the German Rhineland foreign tourists would regularly be induced to buy work from local artists. By the 186os the term 'Engländer' could even be used as a simple substitute for 'wealthy amateur.'110

\footnotetext{
104 Hélène Lafont-Couturier, "Mr Gérôme Works for Goupil," in Gérôme \& Goupil: Art and Enterprise (Paris: Réunion des musées nationaux, 2001), 20-1.

105 Lilian M.C. Randall, ed., The Diary of George A. Lucas: An American Art Agent in Paris, 1857-1909 (Princeton: Princeton University Press, 1979).

106 Dominique Poulot, "Conclusion: L'histoire des collections entre l'histoire de l'art et l'histoire," in Collections et marché de l'art en France 1789-1848, 434-5; Michela Scolaro, "Lorigine des musées égyptiens en Italie et en France," in Collections et marché de l'art en France 1789-1848, 349-58.

107 Baldassare, "Buenos Aires."

108 Thomson, "Theo van Gogh: An Honest Broker," 79.

109 Artemos, "Lettres sur l'exposition," Journal du commerce, 22 August 1849: 1.

110 Lenman, Artists and Society in Germany, 157.
} 
Again, dealers could follow the dictates of foreign taste, which is what Goupil seems to have done in his conquest of the American art market. ${ }^{111}$ They could also try to create new markets abroad, however, and guide the taste of collectors through publications and exhibitions, as Durand-Ruel successfully did in America. ${ }^{112}$

\section{Educating the Market: National Schools for New Audiences}

The internationalisation of the art market was accompanied, and indeed accommodated, by the rapidly expanding field of art literature. Books and auction catalogues were increasingly distributed through networks that spanned Europe and beyond, while journals and newspapers actively sought subscribers abroad. Specialised art periodicals also increasingly paid attention to exhibitions, auctions and other topical events taking place abroad and of possible interest for art enthusiasts, often enlisting the help of local correspondents in cities throughout Europe. They also sometimes published in-depth analyses of artistic developments abroad or monographic studies devoted to foreign artists. More ambitious introductions to foreign art, old or contemporary, were published in the form of book-length studies and monographs. Authors like Théophile Gautier and Ernest Chesneau seized the occasion offered to them by the presence of art from all over Europe at the universal exhibitions in Paris of 1855 and 1867 , respectively, to publish survey texts on the recent development and state of the arts in the different European countries. ${ }^{113}$ Chesneau further specialised in English art and regularly published on topics pertaining to that field. ${ }^{114}$ In England a flow of similar publications saw the light. Leading art critics like Joseph Beavington Atkinson and Philip Gilbert Hamerton wrote on the German, French and other continental schools, while William Bell Scott authored a trilogy on the French, German and Belgian-Dutch schools in the early 1870 illustrated with carbon photographs. ${ }^{115}$

\footnotetext{
111 Penot, La Maison Goupil, 307-16.

112 Thompson, "Paul Durand-Ruel," 106-19.

113 Théophile Gautier, Les Beaux-arts en Europe (Paris: Michel Lévy Frères, 1855); Ernest Chesneau, Les Nations rivales dans l'art (Paris: Didier, 1868).

114 See for instance: Ernest Chesneau, La Peinture anglaise (Paris: A. Quantin, 1882).

115 See for instance: Joseph Beavington Atkinson, An Art Tour to Northern Capitals of Europe (London: Macmillan, 1873); Id., The Schools of Modern Art in Germany (London: Seeley Jackson \& Halliday, 1880); Philip Gilbert Hamerton, The Present State of the Fine Arts in France (London: Seeley, 1892); William Bell Scott, Gems of French Art, Gems of Modern Belgian Art and Gems of Modern German Art (London: George Routledge \& Sons, 1871, 1872 and 1873).
} 
Since the art press was closely interwoven with the market, it should not come as a surprise that some of the editorial choices made with regard to foreign art were at least partially informed by commercial interests (as they were with regard to domestic art). The short-lived art journal La Chronique Internationale des Beaux-Arts, published between 1866 and 1868 by the International Society of Fine Arts in London and intended for an international audience, was mostly a commercial vehicle used by the Belgian art dealer Léon Gauchez to promote his stock. ${ }^{116}$ It is probably no coincidence either that virtually all of the artists discussed in the thirteen articles on contemporary Belgian art published by James Dafforne in the influential English periodical The Art-Journal in 1866 and 1867 were represented in England by Ernest Gambart, whose good relations with The Art-Journal are well known. ${ }^{117}$

More important for the present book volume than such examples of direct commerce-driven machinations, however, is the broader role played by the art press in mediating between artists and dealers on the one hand and the new and expanding art audiences on the other. The growing field of art literature indeed not only offered audiences knowledge of and information on the history and contemporary developments of the arts at home and abroad, but it also provided them with conceptual and terminological tools to understand, evaluate or simply respond to art. The creation of this new economy of knowledge, offered and purchased by various actors and in various contexts, was essential for the international expansion of the art market. It is also within this economy of knowledge that the importance of the "national" in the internationalisation of the art market becomes clear; for paradoxically at first sight, it was ideas of national identity and categories related to these ideas that became central in this new economy of knowledge, facilitated and ultimately even propelled the international expansion of the art market.

In order to trace this development, it is necessary to briefly take a step back in time. National identity played a major role in the formation of art markets prior to the nineteenth century. Anthony Smith has argued that the establishment of the art market in seventeenth-century Dutch cities went hand in hand with the early rise of bourgeois nationalism. The popularity of Dutch landscapes and genre paintings with the new bourgeois art buying

116 Ingrid Goddeeris, "Forward!- -Selfhelp.-Self-respect: Léon Gauchez (1825-1907) et la Société Internationale des Beaux-Arts de Londres," in Animateur d'art. Dealer, collector, critic, publisher ...: the animateur d'art and his multiple roles. Pluridisciplinary research of these disregarded cultural mediators of the 19th and 2oth centuries, eds. Ingrid Goddeeris and Noémie Goldman (Brussels: Royal Museums of Fine Arts of Belgium, 2015), esp. $146-8$.

117 Baetens, "The Belgian Brand," 1294. 
classes in seventeenth-century Holland was, according to Smith, not only due to the distinct educational backgrounds of these classes, the difficulty of religious subject matter after the Reformation or the more limited availability of space in the houses of Dutch merchants and entrepreneurs, but it was also a consequence of the new form of national "belonging" that the citizens of the Republic adhered to. ${ }^{118}$ Contrary to the aristocracy, which privileged forms of solidarity based on the transnational blood ties of kinship, the new bourgeois class spawned by the advent of capitalism, constructed new forms of solidarity grounded in an imagined communality for which nationalist thinking provided the basis. ${ }^{119}$ This logically resulted in outspoken taste preferences for types of art that visualised, represented and constructed the national identity that these new classes built and shared. Thus, Dutch burghers could see both the reflection and the confirmation of "their" way of life in the genre scenes produced by their autochthonous artists, or identify with and claim their homeland in locally produced Dutch landscapes. ${ }^{120}$

Looking at the example of seventeenth-century Holland, the logic of nationalist thinking seems hard to reconcile with the internationalisation of the art market. The nineteenth century, however, presents a distinctively different picture. Capitalism and nationalism further matured, and high art was probably more important than ever before or afterwards to support nationalist agendas or serve the interests of the art buying elites. However, as capitalism gradually started to globalise, the character of its alliance with nationalist thinking in the art market also changed. Clearly, the further conjunction of capitalism and nationalist thinking did not lead to the mere coexistence of a number of self-supporting, discrete, national art markets with local producers supplying "national" art to local audiences, all grounded in exclusively nationalist, or patriotic, taste preferences. On the contrary, the art market became more international than ever before. Again, however, the ideas and forms of knowledge necessary for these market developments were provided by nationalist thinking, not in the narrow sense of a closed and inward-looking patriotic position, but rather in the broader sense of an ideological conviction of the existence of an order dividing the world in distinctive nations, all of which have their own clearly defined cultural identities, and the adoption of rational categories based on this conviction. ${ }^{121}$ This new system of knowledge provided a common

118 Anthony D. Smith, The Nation Made Real: Art and National Identity in Western Europe, 1600-1850 (Oxford: Oxford University Press, 2013), 79-81.

119 Benedict Anderson, Imagined Communities: Reflections on the Origin and Spread of Nationalism (London - New York: Verso, 1991), 77.

120 Anderson, Imagined Communities, 77; Smith, The Nation Made Real, 79-81.

$121 I d ., 73 \mathrm{ff}$. 
intellectual framework and thus facilitated and stimulated the trade in art across borders.

In their book on the development of the art market in Britain, Thomas Bayer and John Page have described how the art market, like any other capitalist market, strives to maximise the exchangeability of goods. ${ }^{122}$ The economy of knowledge plays a key role in this process, firstly because a system or "habitus" of conceptual categories and criteria shared by all actors in the market provides a common standard to calculate the desirability of the exchange of specific goods on the supply and demand side and to determine the conditions attached by these actors to such an exchange, and secondly because informational efficiency, or equal access to information for different actors, makes the market more transparent and thus further stimulates the exchange of goods, regardless of the commercial benefits that information asymmetry may yield to individual agents in the market. ${ }^{123}$

In the expanding market of the "long" nineteenth century, then, new systems of knowledge had to be put in place in order to maximise exchanges between the growing groups of consumers of art on the one hand and the producers and distributors of art who responded to the increased demand on the other. Nineteenth-century representations of exhibitions and commercial galleries make evident just how important access to information was for these new audiences: while the select connoisseurs in Alma-Tadema's The Picture Gallery seem to be able to form their own opinions, aided only perhaps by Gambart's explanations, in most of these depictions, visitors carry catalogues and other little booklets with them, trying to make sense of what they see or pointing out certain features of the works on view to each other (Fig. 1.3). The increased possibilities of trading across national borders, now, logically suggested the central role of categories pertaining to national identity in these systems of knowledge, most conspicuously in the rational organisation of works of art in national schools. Such a classification could serve as a shared system of valuation (in the broadest, not strictly pecuniary sense) for art that increasingly circulated between different national markets.

Neither these new systems of art knowledge nor the type of nationalist thinking that characterised them were, of course, solely developed in the field of commerce. But even in its most emphatically anti-commercial guises,

\footnotetext{
122 Bayer and Page, The Development, $14 \mathrm{ff}$.

123 See for instance: Thomas M. Bayer and John Page, "Arthur Tooth: A London Dealer in the Spotlight, 1870-71," in Nineteenth-Century Art Worldwide 9, no. 1 (2010), http://www .19thc-artworldwide.org/springio/arthur-tooth, esp. note 28 .
} 


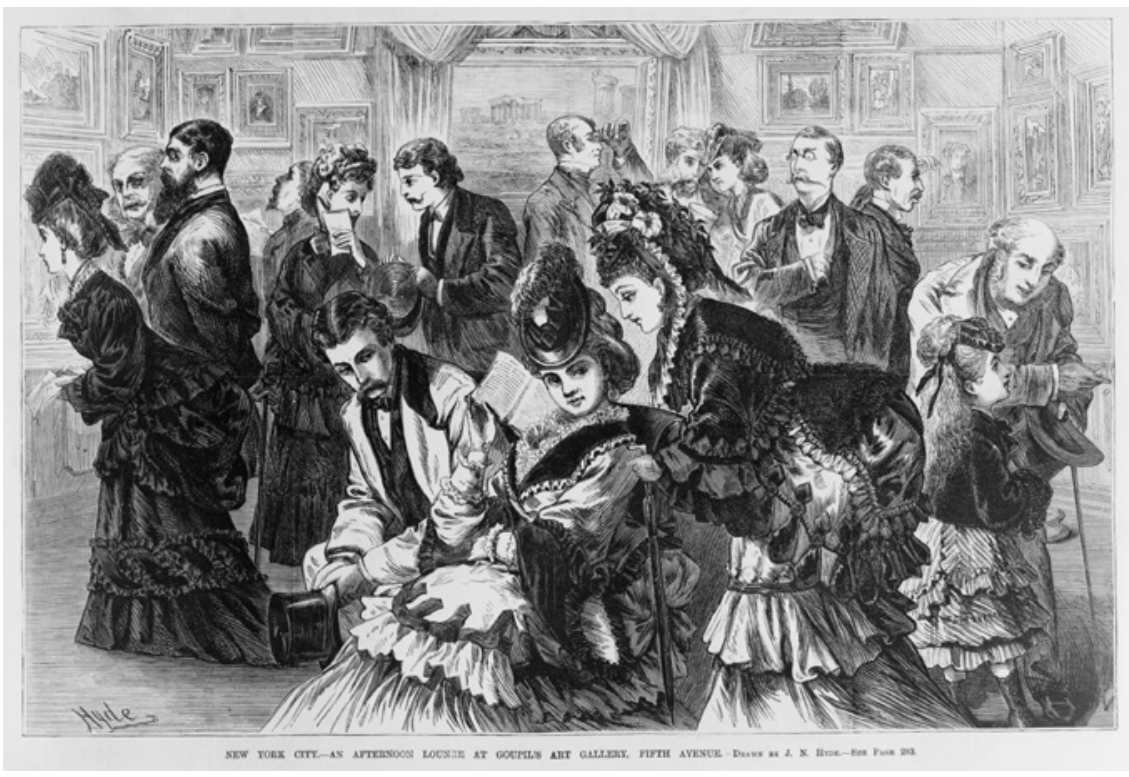

FIGURE 1.3 Anon. after J.N. Hyde, New York City—An Afternoon Lounge at Goupil's Art Gallery, Fifth Avenue, in Frank Leslie's Illustrated Newspaper (13 July 1872): 280

modes of art knowledge based on national categories could stimulate the exchangeability of artistic goods and facilitate the opening up of national art markets. The emergence of public museums in the late eighteenth and nineteenth centuries, to take the most obvious example, was usually accompanied by a marked anti-commercial stance: the rhetoric of public museums rejected the realm of commerce and prioritised education and moral elevation. The interests of capitalism, however, were never really absent. It has been observed, for instance, that public museums clearly served the governing elite's agenda of control and assimilation, aimed at the absorption of 'the problematic "masses" within the legitimate confines of liberal power.'124 However, the museum and its educational project could also affect the market in a more direct way. Moulding museum visitors into ideal citizens could ultimately also mean turning them into ideal consumers. Presenting to them the products of 'the most evolved and civilised culture of which the human spirit is capable', all 'rationally organised and clearly labelled,' could also mean equipping them with the

124 Nick Prior, Museums and Modernity: Art Galleries and the Making of Modern Culture (Oxford - New York: Berg, 2002), 50-1. 
knowledge required for the consumption of art in an expanding, internationalising world. ${ }^{125}$

When we consider this in the context of the internationalisation of the art market, it becomes clear that the reorganisation of public art collections in the late eighteenth and early nineteenth centuries into separate sections that presented works of art from different countries not only educated museum visitors by means of a new mode of rational art knowledge based on national categories, but indeed it also provided them with the conceptual instruments necessary to consume art in an increasingly international context. ${ }^{126}$ As the century progressed, evolving ideas about art further boosted the commercial potential of this type of consumption-inducing education. Originally, the educational goal behind museum installations based on the distinction between national schools was to encourage the viewer to compare the different schools and to evaluate them on the basis of a set of supposedly objective and universal criteria derived from academic theory: the different national schools could then be judged, for better or worse, by their allegiance, or lack thereof, to academic standards. ${ }^{127}$ Nineteenth-century romanticism's endorsement of individual differences and its interest in national character, however, gradually led to a more equal treatment and appreciation of the different national schools, even if this theoretical impartiality was often kept in check by nationalist, patriotic considerations. ${ }^{128}$ As a result of this democratisation of taste, the restructuring of art knowledge along national categories no longer merely made the international market more transparent: the very idea of treating all schools, at least in theory, on an equal footing could also massively increase the fluidity of goods in the market. Henceforward, national differences in art production no longer had to be impediments to the internationalisation of the art market, as they may have been in the face of the now superseded universal academic standards. They could now actually stimulate the circulation of goods and open up major new markets by securing a richer supply and catering to more varied tastes or demands.

125 Carol Duncan, Civilizing Rituals: Inside Public Art Museums (London - New York: Routledge, 1995), 26.

126 Charlotte Klonk, Spaces of Experience: Art Gallery Interiors from 1800 to 2000 (New Haven - London: Yale University Press, 2009), 21-2.

127 Id., 23.

128 Id., 37-43; Dominique Poulot, "The Changing Role of Art Museums," in National Museums and Nation-Building in Europe 1750-2010: Mobilization and Legitimacy, Continuity and Change, eds. Peter Aronsson and Gabriella Elgenius (London - New York: Routledge, 2015), 99-100. 
The same nationalist ideological groundwork that structured public museums and their output of knowledge also characterised the evolving art discourse of the time in newspapers, periodicals, books and other publications. Both in its popular, commercial manifestations and in its more scholarly form, the production of this type of art discourse and art knowledge was intricately interwoven with market interests. ${ }^{29}$ In a more general sense, it was also in this type of publications that the commercial potential of a conceptual apparatus based on national categories could be fully developed. As Julie Codell has explained for the British context, the production of this art discourse changed quickly following the advent of new consumers in the market and the consequent changes in the composition of traditional art audiences: 'no longer a matter of identifying art consumption with the interests and ambitions of a relatively limited and homogeneous class, art writing for a wide audience became taxed with the burden of finding common ground and shared experiences to bind these diverse populations.' ${ }^{130}$ In order to create this 'common ground,' art critics, art historians and other producers of art discourse developed a system of categories, taxonomies and other forms of knowledge that enabled broader audiences to engage with art. Patriotic ideas sometimes played a role in this new system of knowledge, as critics, art historians and periodicals could actively endorse and support their national schools. ${ }^{131}$ Authors sometimes also adopted a more open international perspective and even promoted certain types of foreign art. ${ }^{132}$ What both positions shared was that notions of national identity provided authors, and subsequently their readers, with the conceptual framework for their analyses and evaluations of art from all nations: artists and works of art could be examined and judged on the basis of their relation with the national school to which they belonged and the characteristics ascribed to

129 Ivan Gaskell, "Tradesmen as Scholars: Interdependencies in the Study and Exchange of Art," in Art History and its Institutions: Foundations of a Discipline, ed. Elizabeth Mansfield (London - New York: Routledge, 2002), 146-62; Antoinette Friedenthal, "John Smith, his Catalogue Raisonné of the Most Eminent Dutch, Flemish, and French Painters (18291842) and the 'stigma of PICTURE DEALER," Journal of Art Historiography 5, no. 9 (2013): $1-20$.

130 Julie F. Codell, The Victorian Artist: Artists' Lifewritings in Britain, ca. 1870-1910 (Cambridge - New York: Cambridge University Press, 2003), 21.

131 See for instance for the British context: Pamela Fletcher and Anne Helmreich, "The Periodical and the Art Market: Investigating the 'Dealer-Critic System' in Victorian England," Victorian Periodicals Review 41, no. 4 (2008): 334-5; Katherine Haskins, The ArtJournal and Fine Art Publishing in Victorian England, 1850-1880 (Farnham: Ashgate, 2012), esp. 91-136; Codell, The Victorian Artist, 24 ff.

132 Fletcher and Helmreich, "The Periodical," 324 and 335. 
this school, or, in a larger perspective, even in relation to the nation that had produced this school, its people and its history.

Accordingly, as the international circulation of works of art increased, French, Belgian and other salonniers began to reserve a special place in their exhibition reviews for a discussion of the work of participating foreign artists, frequently elaborating on the nature and development of the nations and national schools to which these artists belonged. ${ }^{133}$ This approach crystallised most clearly in the massive production of art discourse around the Paris $e x$ position universelle of 1855 , when art critics systematically related the works of art exhibited by the various national sections to the state of the sciences, industry, politics and culture in the nations that presented them-in short to the "genius" or national character of the nations that had produced these works. ${ }^{134}$ Equipped with this intellectual framework, visitors to the exposition universelle could not only educate themselves by comparing the artistic productions from the various national schools, but they could also consume these productions. Four years earlier, in 1851 , they had been able to do so in an even more literal way at the so-called General Exhibition of Pictures by the Living Artists of the Schools of All Countries, an international exhibition of contemporary art organised on the fringes of the Great Exhibition in London. The General Exhibition claimed to further a disinterested educational agenda, similar to that of the Great Exhibition, by giving the public the opportunity to compare the different national schools of painting. The show was, however, an unambiguously commercial selling exhibition where visitors could not only look at works of art from all countries, but they were also encouraged to buy them. ${ }^{135}$

Thus, even if the goal of the taxonomies and the wide net of references to foreign art or old masters in the discourse produced by writers on art was, at least in part, to claim art as an entirely autonomous field in which these authors could act as professional arbiters of taste and educators, regardless of monetary interests, the commercial dimension of this discourse is undeniable. ${ }^{136}$ It is easily identifiable in the operations and strategies of dealers and other unmistakeably commercial actors who were able to capitalise on the newly created body of knowledge. The discursive use of European schools as categories in British auction catalogues of the eighteenth century already

133 See for instance: Verschaffel, "Art and Nationality," 123-37.

134 Patricia Mainardi, Art and Politics of the Second Empire: The Universal Expositions of 1855 and 1867 (New Haven - Londen: Yale University Press, 1987), 97.

135 Baetens, "The General Exhibition of Pictures of 1851," 270-89.

136 Elizabeth Prettejohn, "Aesthetic Value and the Professionalization of Victorian Art Criticism 1837-78," Journal of Victorian Culture 2, no. 1 (1997): esp. 85. 
evidences a growing British connoisseurship and higher standards of valuation; the changing vocabulary in these commercial documents equipped the British spectators with a value system to deal with and talk about art, as Bénédicte Miyamoto illustrates in her contribution to this volume. John Boydell's Shakespeare Gallery aimed to raise the British national school to the same standard as the leading national schools on the Continent, but also to market the now distinctively identifiable school of British painting abroad, especially in France. ${ }^{137}$ From 1792 to 1796 the influential French art dealer JeanBaptiste-Pierre Lebrun published the Galerie des peintres flamands, hollandais et allemands, a large three volume book dedicated exclusively to the schools of the North. The book not only provided collectors with knowledge that enabled them to distinguish amongst the different schools of the North, but it also stimulated them to acquire works by the lesser-known artists belonging to these schools. ${ }^{138}$ In the early nineteenth century the American John Wilson ran the so-called European Museum in London, a museum allegedly founded in 1789 that was, in fact, a commercial gallery that functioned as a marketplace for mostly low-end old master pictures. Its name clearly inscribed it into the logic and internationalist perspective of national schools as increasingly adopted by public art collections, thus capitalising on the commercial potential of this new taxonomy. ${ }^{139}$ A similar exhibition and retail space, called the Musée Européen, was run in Paris in the 1820s. ${ }^{140}$

As the nineteenth century progressed, national categories were increasingly mobilised in art discourse directly addressed to consumers and unambiguously aimed at stimulating consumption. Dealers could simply sing the praises of the national schools they marketed or ask critics to do so for them. Sometimes dealers also made more subtle use of national categories. The catalogue that accompanied the 1888 selling exhibition of the work of Adolphe Monticelli organised in London by Dowdeswell \& Dowdeswell's gallery, for instance, suggested a close harmony between the art of Monticelli and American and Scottish aesthetic sensibilities: 'American and Scotch eyes have been to the

137 Dias, Exhibiting Englishness, esp. 65-125 and $217 \mathrm{ff}$.

138 Aude Prigot, "Une entreprise franco-hollandaise: la galerie des peintres flamands, hollandais et allemands de Jean-Baptiste-Pierre Lebrun, 1792-1796," in Les Échanges artistiques entre les anciens Pays-Bas et la France, 1482-1814, eds. Gaëtane Maës and Jan Blanc (Turnhout: Brepols, 2010), 212.

139 Camilla Murgia, "From Private to National: Exhibiting Fine Arts in London around 180o," forthcoming.

140 Hélène Sécherre, "Le marché des tableaux italiens à Paris sous la Restauration (1815-1830): collectionneurs, marchands, spéculateurs," in Collections et marché de l'art en France 1789$1848,168-9$. 
fore in appreciating Monticelli's work [...] and the story of Monticelli's pictures is a further proof that Englishmen, and even he artist's compatriots, must give way before Scotchmen and Americans in swift and unhesitating understanding of a new and felicitous pictorial interpretation of Nature's facts. ${ }^{141}$

Nineteenth-century dealers in contemporary art, like Gambart, Stevens and many others, developed their own market identities based on national categories, promoting specific national schools as veritable "national brands," in what could be seen as an early and distinct emanation of the 'ideological dealer,' a term coined by Robert Jensen for a number of late nineteenth and early twentieth-century dealers devoted to a particular group of artists. ${ }^{142}$ The system of promoting national "brands" of art was so widespread that it accommodated collaborations between dealers rather than hampering them, even in a market where product differentiation is key. ${ }^{143}$ In 1854 , for instance, the Belgian dealer Gustave Coûteaux declined to send any of his stock to London for Gambart's first French exhibition because, as he explained in a letter, he specialised in contemporary Belgian, not French art. When Gambart later rebranded his gallery as a retail place for both contemporary French and Belgian painting, however, many of the artists from Coûteaux's stable would also find their way to Gambart's gallery in London, probably with Coûteaux's blessing. ${ }^{144}$ The reconceptualisation of the London art district as a 'Grand Tour on Bond Street' or a huge bazaar or universal exhibition, where works from the different national schools were offered by a wide range of specialised niche retailers, was, then, only the final stage of this development. ${ }^{145}$

\section{Conclusion}

All of these examples clearly indicate that nationalist modes of thinking on the one hand and the internationalisation of the art market on the other were not at odds but, on the contrary, mutually reinforced one another. The expansion of the market across national borders necessitated the development of new modes of art knowledge, in which national categories played an essential role. Thinking along these national categories did not necessarily make artists or collectors defend rigidly defined, patriotic positions. Rather, it often made

\footnotetext{
141 Quoted in: Fowles, Van Gogh's Twin, 35.

142 Jensen, Marketing Modernism, 50-1.

143 See on product differentiation in the art market: Bayer and Page, "Arthur Tooth," esp. note 72 .

144 Baetens, "The Belgian Brand," $1285 \mathrm{ff}$.

145 Fletcher, "The Grand Tour," 139-53.
} 
them 'devotees to nationalism in general.'146 Artists, for instance, not only painted their own national histories but became interested in other nations' pasts, while collectors became increasingly sensitive to what they perceived as typical art from foreign countries. Critics defended national or foreign schools in partisan ways or promoted the benefits of emulative competition or simple exchanges between art communities across borders. Dealers attempted to gauge or influence taste preferences abroad, marketing foreign artists from their stables or stimulating their artists to adapt to the exigencies of new markets. Collectors, finally, developed their tastes on the basis of nationally defined categories. This could lead to a preference for autochthonous art, for foreign art, or to a taste for art from abroad that tied in with collectors' own national traditions, as in the case of the British predilection for rustic and fishing scenes from the Hague school that went well with British traditions. ${ }^{147}$

In all of these operations, artists, dealers, critics, amateurs and others embraced ideas of national identity as a common denominator for art knowledge. It was this system of knowledge that provided audiences, suppliers, middlemen and other actors with the shared conceptual framework required to cope with art in an expanding art world, thus increasing the market's transparency in spite of its growth and facilitating the international fluidity of goods and persons. The nineteenth-century art market, in other words, became radically international, but it could only do so on the firm basis of ideas tied to national identity.

\section{References}

Ahrens, Anna. Der Pionier. Wie Louis Sachse in Berlin den Kunstmarkt erfand. Cologne - Weimar - Vienna: Böhlau, 2017.

Alting van Geusau, Sylvia. "Kunst aan de Kalverstraat. De handelszin van Frans Buffa \& Zonen." In Kunsthandel Frans Buffa \& Zonen 1790-1950, edited by Sylvia Alting van Geusau, Mayken Jonkman, and Aukje Vergeest, 37-59. Zwolle: Waanders, 2016.

Anderson, Benedict. Imagined Communities: Reflections on the Origin and Spread of Nationalism. London - New York: Verso, 1991.

Anon. "Actualités." La Renaissance. Chronique des arts et de la littérature 11 (1849-50): 36.

Anon. "Commerce de tableaux." Journal des beaux-arts et de la littérature 3 (1861): 183.

146 Smith, The Nation Made Real, 108-9.

147 Helmreich, "The Goupil Gallery," 76. 
Anon. “Art et mercantilisme." L’Art moderne 20 (1900): 89.

Armstrong-Totten, Julia. "Expand the Audience, Increase the Profits: Motivations Behind the Private Contract Sale." In La Circulation des ouvres d'art-The Circulation of Works of Art in the Revolutionary Era, 1789-1848, edited by Roberta Panzanelli and Monica Preti-Hamard, 45-55. Rennes: Presses universitaires de Rennes, 2007.

Artemos. "Lettres sur l'exposition." In Journal du commerce, 22 August 1849: 1.

Asvarisch, Boris I. "Les artistes belges et leurs peintures: le point de vue de la Russie." In Peintures belges de l'Ermitage, edited by Boris I. Asvarisch, 17-79. Venice: Marsilio, 1999 .

Asvarisjtsj, Boris. "De galerie van vorst Aleksandr Gortsjakov." In Verzamelaars in Sint-Petersburg, 66-81. Zwolle: Waanders, 2007.

Asvarisjtsj, Boris. "De galerij van Koesjelev-Bezborodko." In Verzamelaars in SintPetersburg, 82-97. Zwolle: Waanders, 2007.

Atkinson, Joseph Beavington. An Art Tour to Northern Capitals of Europe. London: Macmillan, 1873 .

Atkinson, Joseph Beavington. The Schools of Modern Art in Germany. London: Seeley Jackson \& Halliday, 1880.

Baetens, Jan Dirk. "Vanguard Economics, Rearguard Art: Gustave Coûteaux and the Modernist Myth of the Dealer-Critic System." Oxford Art Journal 33, no. 1 (2010): 25-41.

Baetens, Jan Dirk. "The Belgian Brand: Ernest Gambart and the English Market for Nineteenth-Century Belgian Art, c. 1850-1870." Belgisch Tijdschrift voor Filologie en Geschiedenis - Revue Belge de Philologie et d'Histoire 92, no. 4 (2014): 1277-309.

Baetens, Jan Dirk. "The General Exhibition of Pictures of 1851: National Schools and International Trade in the Mid-Victorian Art Market." Visual Culture in Britain 17, no. 3 (2016): 270-89.

Baldassare, María Isabel. "Buenos Aires: An Art Metropolis in the Late Nineteenth Century." Nineteenth-Century Art Worldwide 16, no. 1 (2017), http://www.19thc-art worldwide.org/index.php/spring17/baldasarre-on-buenos-aires-an-art-metropolisin-the-late-nineteenth-century.

Bätschmann, Oskar. The Artist in the Modern World: The Conflict between Market and Self-Expression. Cologne: DuMont, 1997.

Bayer, Thomas M., and John Page. "Arthur Tooth: A London Dealer in the Spotlight, 1870-71." Nineteenth-Century Art Worldwide 9, no. 1 (2010), http://www.19thc-art worldwide.org/spring10/arthur-tooth.

Bayer, Thomas M., and John R. Page. The Development of the Art Market in England: Money as Muse, 1730-1900. London: Pickering \& Chatto, 2011.

Becker, Edwin, Edward Morris, Elizabeth Prettejohn and Julian Treuherz, eds. Sir Lawrence Alma-Tadema. Zwolle: Waanders, 1996. 
Bionda, Richard. “De afzet van eigentijdse kunst in Nederland.” In De schilders van Tachtig. Nederlandse schilderkunst 1880-1895, edited by Richard Bionda and Carel Blotkamp, 53-74. Zwolle: Waanders, 1991.

Bobet-Mezzasalma, Sophie. "Les galeries lithographiées: de la duchesse de Berry à Artaud de Montor." In Collections et marché de l'art en France 1789-1848, edited by Monica Preti-Hamard and Philippe Sénéchal, 409-30. Rennes: Presses universitaires de Rennes, 2005.

Boime, Albert. "Entrepreneurial Patronage in Nineteenth-Century France." In Enterprise and Entrepreneurs in Nineteenth and Twentieth-Century France, edited by Edward C. Carter II, Robert Forster, and Joseph N. Moody, 137-207. Baltimore London: The John Hopkins University Press, 1976.

Borchert, Till-Holger. "De geschiedenis van het verzamelen van de Oudnederlandse schilderkunst in de negentiende eeuw." In 'Om iets te weten van de oude meesters.' De Vlaamse Primitieven - herontdekking, waardering en onderzoek, edited by Bernhard Ridderbos and Henk van Veen, 140-88. Amsterdam: Sun, 2005.

Burty, Philippe. "L'hôtel des ventes et le commerce de tableaux." In Paris-Guide. Par les principaux écrivains et artistes de la France, vol. 2, 949-62. Paris: Librairie internationale, 1867 .

Chagnon-Burke, Véronique. "Rue Laffitte: Looking at and Buying Contemporary Art in Mid-Nineteenth-Century Paris." Nineteenth-Century Art Worldwide 11, no. 2 (2012), http://www.19thc-artworldwide.org/summer12/veronique-chagnon-burke-lookingat-and-buying-contemporary-art-in-mid-nineteenth-century-paris.

Chaudonneret, Marie-Claude. L'État et les artistes. De la restauration à la monarchie de Juillet (1815-1833). Paris: Flammarion, 1999.

Chaudonneret, Marie-Claude. "Collectionner l'art contemporain (1820-1840). L'exemple des banquiers." In Collections et marché de l'art en France 1789-1848, edited by Monica Preti-Hamard and Philippe Sénéchal, 273-82. Rennes: Presses universitaires de Rennes, 2005.

Chesneau, Ernest. Les Nations rivales dans l'art. Paris: Didier, 1868.

Chesneau, Ernest. La Peinture anglaise. Paris: A. Quantin, 1882.

Codell, Julie F. The Victorian Artist: Artists' Lifewritings in Britain, ca. 1870-1910. Cambridge - New York: Cambridge University Press, 2003.

Dekkers, Dieuwertje. "Jozef Israëls, een succesvol schilder van het vissersgenre." PhD diss., University of Amsterdam, 1994.

Dekkers, Dieuwertje. “'Where Are the Dutchmen?' Promoting the Hague School in America, 1875-1900." Simiolus: Netherlands Quarterly for the History of Art 24, no. 1 (1996): 54-73.

Dias, Rosie. Exhibiting Englishness:John Boydell's Shakespeare Gallery and the Formation of a National Aesthetic. New Haven - London: Yale University Press, 2013. 
Duncan, Carol. Civilizing Rituals: Inside Public Art Museums. London - New York: Routledge, 1995 .

Duncan, Carol, and Allan Walch. "The Universal Survey Museum." Art History 3, no. 4 (1980): 448-69.

Durand-Ruel, Paul. Memoirs of the First Impressionist Art Dealer (1831-1922). Paris: Flammarion, 2014.

Fidell-Beaufort, Madeleine, and Jeanne K. Welcher. "Some Views of Art Buying in New York in the 1870s and 1880s." Oxford Art Journal 5, no. 1 (1982): 48-55.

Fidell-Beaufort, Madeleine. "The American Art Trade and French Painting at the End of the 19th Century." Van Gogh Museum Journal 6 (2000): 101-7.

Filipová, Martha, ed. Cultures of International Exhibitions 1840-1940: Great Exhibitions in the Margins. London - New York: Routledge, 2015.

Fink, Lois Marie. "French Art in the United States, 1850-1870: Three Dealers and Collectors." Gazette des beaux-arts 120 (1978): 87-100.

Fletcher, Pamela M. "Creating the French Gallery: Ernest Gambart and the Rise of the Commercial Art Gallery in Mid-Victorian London." Nineteenth-Century Art Worldwide 6, no. 1 (2007), http://www.19thc-artworldwide.org/springo7/46springo7/springo7article/143-creating-the-french-gallery-ernest-gambart-and-therise-of-the-commercial-art-gallery-in-mid-victorian-london.

Fletcher, Pamela M. "The Grand Tour on Bond Street: Cosmopolitanism and the Commercial Art Gallery in Victorian London." Visual Culture in Britain 12, no. 2 (2011): 139-53.

Fletcher, Pamela M., and Anne Helmreich. "The Periodical and the Art Market: Investigating the 'Dealer-Critic System' in Victorian England." Victorian Periodicals Review 41, no. 4 (2008): 323-51.

Fowles, Frances. Van Gogh's Twin: The Scottish Art Dealer Alexander Reid 1854-1928. Edinburgh: National Galleries of Scotland, 2010.

Friedenthal, Antoinette. "John Smith, his Catalogue Raisonné of the Most Eminent Dutch, Flemish, and French Painters (1829-1842) and the 'stigma of PICTURE DEALER'." Journal of Art Historiography 5, no. 9 (2013): 1-20.

Galenson, David W., and Robert Jensen. "Careers and Canvases: The Rise of the Market for Modern Art in Nineteenth-Century Paris." Van Gogh Studies 1 (2007): 137-66.

Gaskell, Ivan. "Tradesmen as Scholars: Interdependencies in the Study and Exchange of Art." In Art History and its Institutions: Foundations of a Discipline, edited by Elizabeth Mansfield, 146-62. London - New York: Routledge, 2002.

Gautier, Théophile. Les Beaux-arts en Europe. Paris: Michel Lévy frères, 1855.

Gerard-Powell, Véronique. "Les collections des officiers de l'armée impériale pendant la campagne d'Espagne: un butin très varié." In Collections et marché de l'art en France 1789-1848, edited by Monica Preti-Hamard and Philippe Sénéchal, 305-17. Rennes: Presses universitaires de Rennes, 2005.

Gérôme \& Goupil: Art and Enterprise. Paris: Réunion des musées nationaux, 2001. 
Goddeeris, Ingrid. "Forward! —Selfhelp.—Self-respect: Léon Gauchez (1825-1907) et la Société Internationale des Beaux-Arts de Londres." In Animateur d'art. Dealer, collector, critic, publisher...: the animateur d'art and his multiple roles. Pluridisciplinary research of these disregarded cultural mediators of the 19th and 2oth centuries, edited by Ingrid Goddeeris and Noémie Goldman, 141-55. Brussels: Royal Museums of Fine Arts of Belgium, 2015.

Hamerton, Philip Gilbert. The Present State of the Fine Arts in France. London: Seeley, 1892.

Haskins, Katherine. The Art-Journal and Fine Art Publishing in Victorian England, 1850-1880. Farnham: Ashgate, 2012.

Helmreich, Anne. "The Art Dealer and Taste: The Case of David Croal Thomson and the Goupil Gallery, 1885-1897." Visual Culture in Britain 6, no. 2 (2005): 31-49.

Helmreich, Anne. "The Goupil Gallery at the Intersection between London, Continent, and Empire." In The Rise of the Modern Art Market in London, 1850-1939, edited by Pamela Fletcher and Anne Helmreich, 65-84. Manchester - New York: Manchester University Press, 2011.

Hinterding, Erik, and Femy Horsch. 'A Small but Choice Collection': The Art Gallery of King Willem II of the Netherlands (1792-1849)." Simiolus: Netherlands Quarterly for the History of Art 19, no. 1-2 (1989): 4-122.

Hoogenboom, Annemieke. De stand des kunstenaars. De positie van kunstschilders in de eerste helft van de negentiende eeuw. Leiden: Primavera, 1993.

Hoogenboom, Annemieke. "Art for the Market: Contemporary Painting in the Netherlands in the First Half of the Nineteenth Century." Simiolus: Netherlands Quarterly for the History of Art 22, no. 33 (1993-94): 129-47.

Hoozee, Robert. “Barbizon en België.” In De schoolvan Barbizon. Franse meesters van de 19de eeuw, edited by John Sillevis and Hans Kraan, 112-27. Ghent: Museum of Fine Arts, 1985 .

Houser, Craig. "Disharmony and Discontent: Reviving the American Art-Union and the Market for United States Art in the Gilded Age." Nineteenth-Century Art Worldwide 11, no. 2 (2012), http://www.19thc-artworldwide.org/summer12/ craig-houser-disharmony-and-discontent.

Huemer, Christian. "Crossing Thresholds: The Hybrid Identity of Late NineteenthCentury Art Dealers." In Crossing Cultures: Conflict, Migration and Convergence, edited by Jaynie Anderson, 1007-11. Melbourne: Miegunyah Press, 2009.

Jaeger, Susanne. Alexander S. Stroganov (1733-1811). Kunstsammler und Mäzen im Russland der Aufklärung. Cologne: Böhlau, 2007.

Jensen, Robert. Marketing Modernism in Fin-de-Siècle Europe. Princeton: Princeton University Press, 1994.

Jonkman, Mayken. “Frederik Hendrik Kaemmerer. De lieveling van de kunstmarkt.” In Nederlanders in Parijs 1789-1914, edited by Mayken Jonkman, 131-47. Bussum: Thoth, 2017. 
Klonk, Charlotte. Spaces of Experience: Art Gallery Interiors from 1800 to 2000 . New Haven - London: Yale University Press, 2009.

Lacourt, Jeanne-Bathilde, ed. Picasso, Léger, Masson: Daniel-Henry Kahnweiler et ses peintres. Villeneuve-d'Ascq: LaM, 2013.

Lafont-Couturier, Hélène. "Mr Gérôme works for Goupil." In Gérôme \& Goupil: Art and Enterprise, 13-29. Paris: Réunion des musées nationaux, 2001.

Lenman, Robin. Artists and Society in Germany 1850-1914. Manchester - New York: Manchester University Press, 1997.

Maas, Jeremy. Gambart: Prince of the Victorian Art World. London: Barrie and Jenkins, 1975 .

Maas, Jeremy. Holman Hunt and the Light of the World. Aldershot: Wildwood House, 1984.

Mainardi, Patricia. Art and Politics of the Second Empire: The Universal Expositions of 1855 and 1867. New Haven - Londen: Yale University Press, 1987.

Mainardi, Patricia. "The 19th-Century Art Trade: Copies, Variations, Replicas." Van Gogh Museum Journal 6 (2000): 62-73.

McClellan, Andrew. Inventing the Louvre: Art, Politics, and the Origins of the Modern Museum in Eighteenth-Century Paris. Berkeley - Los Angeles: University of California Press, 1999.

McIntosh, DeCourcy E. "Goupil's Album: Marketing Salon Painting in the Late Nineteenth Century." In Twenty-First-Century Perspectives on Nineteenth-Century Art: Essays in Honor of Gabriel P. Weisberg, edited by Petra ten-Doesschate-Chu and Laurinda S. Dixon, 77-84. Newark: University of Delaware Press, 2008.

Miquel, Pierre. Le Paysage français au XIX esiècle 1824-1874. L'école de la nature. Martinelle: Maurs-la-Jolie, 1975.

Morris, Edward. French Art in Nineteenth-Century Britain. New Haven - London: Yale University Press, 2005.

Murgia, Camilla. "From Private to National: Exhibiting Fine Arts in London around 180o." forthcoming.

Nerlich, France. La Réception de la peinture française en Allemagne, 1815-1870. Paris: Éditions de la maison des sciences de l'homme, 2009.

Nerlich, France. "La fin de l'exclusion artistique. Le marchand d'art berlinois Louis Friedrich Sachse à la conquête de la province." In Marché(s) de l'art en province 1870-1914, edited by Laurent Houssais and Marion Lagrange, 143-6o. Bordeaux: Presses universitaires de Bordeaux, 2010.

Nonne, Monique. "Artistieke wisselwerking: een paar voorbeelden." In Parijs-Brussel, Brussel-Parijs. Realisme, impressionisme, symbolisme, art nouveau. De artistieke dialoog tussen Frankrijk en België, 1848-1914, edited by Robert Hoozee and Anne Pingeot, 42-53. Antwerp: Mercatorfonds, 1997.

Ogonovszky, Judith. “Charles Rogier, mécène interposé d'un art national." In L'Argent des arts. La politique artistique des pouvoirs publics en Belgique de 1830 à 1940, edited 
by Ginette Kurgan-van Hentenryk and Valérie Montens, 63-71. Brussels: Éditions de l'Université de Bruxelles, 2001.

Ogonovszky, Judith. "Le Commerce de tableaux en Belgique sous la règne de Léopold Ier (1831-1865): première vue d'ensemble." Art \& fact 21 (2002): 6-14.

Ormrod, David. "Dealers, Collectors and Connoisseurship in Seventeenth \& EighteenthCentury London 1660-1760." In Kunstsammeln und Geschmack im 18. Jahrhundert, edited by Michael North, 15-23. Berlin: Berliner Wissenschafts-Verlag, 2002.

Panzanelli, Roberta, and Monica Preti-Hamard, eds. La Circulation des œuvres d'artThe Circulation of Works of Art in the Revolutionary Era, 1789-1848. Rennes: Presses universitaires de Rennes, 2007.

Penot, Agnès. La Maison Goupil. Galerie d'art internationale au XIXe siècle. Paris: Mare \& Martin, 2017 .

Penot, Agnès. "The Perils and Perks of Trading Art Overseas: Goupil's New York Branch." Nineteenth-Century Art Worldwide 16, no. 1 (2017), http://www.19thc-art worldwide.org/index.php/spring17/penot-on-the-perils-and-perks-of-trading-artoverseas-goupils-new-york-branch.

Péronnet, Benjamin. "La presse et le marché de l'art, de la Révolution à la Restauration." In Collections et marché de l'art en France 1789-1848, edited by Monica Preti-Hamard and Philippe Sénéchal, 97-110. Rennes: Presses universitaires de Rennes, 2005.

Pittore, E. [Emile Leclercq]. "Collections particulières d'objets d'art. Galerie de M. Van Becelaere." Uylenspiegel.Journal des ébats artistiques et littéraires 2, no. 6 (1857-58):1-2. Poulot, Dominique. "The Changing Role of Art Museums." In National Museums and Nation-Building in Europe 1750-2010: Mobilization and Legitimacy, Continuity and Change, edited by Peter Aronsson and Gabriella Elgenius, 89-118. London - New York: Routledge, 2015.

Poulot, Dominique. "Conclusion: L'histoire des collections entre l'histoire de l'art et l'histoire." In Collections et marché de l'art en France 1789-1848, edited by Monica Preti-Hamard and Philippe Sénéchal, 431-43. Rennes: Presses universitaires de Rennes, 2005.

Prettejohn, Elizabeth. "Aesthetic Value and the Professionalization of Victorian Art Criticism 1837-78." Journal of Victorian Culture 2, no. 1 (1997): 71-94.

Prigot, Aude. "Une entreprise franco-hollandaise: la galerie des peintres flamands, hollandais et allemands de Jean-Baptiste-Pierre Lebrun, 1792-1796." In Les Échanges artistiques entre les anciens Pays-Bas et la France, 1482-1814, edited by Gaëtane Maës and Jan Blanc, 215-22. Turnhout: Brepols, 2010.

Randall, Lilian M.C., ed. The Diary of George A. Lucas: An American Art Agent in Paris, 1857-19o9. Princeton: Princeton University Press, 1979.

Reist, Inge. "The Fate of the Palais Royal Collection: 1791-180o." In La Circulation des ouvres d'art - The Circulation of Works of Art in the Revolutionary Era, 1789-1848, edited by Roberta Panzanelli and Monica Preti-Hamard, 27-44. Rennes: Presses universitaires de Rennes, 2007. 
Prior, Nick. Museums and Modernity: Art Galleries and the Making of Modern Culture. Oxford - New York: Berg, 2002.

Reitlinger, Gerald. The Economics of Taste: The Rise and Fall of Picture Prices 1760-1960. New York: Hacker Art Books, 1982.

Robbins, Anne. "À la conquête de Londres." In Paul Durand-Ruel. Le pari de l'impressionisme, edited by Sylvie Patry, 134-49. Paris: Réunion des musées nationaux, 2014.

Sachko Macleod, Dianne. Art and the Victorian Middle Class: Money and the Making of Cultural Identity. Cambridge: Cambridge University Press, 1996.

Savoy, Bénédicte. "Conquêtes et consécrations. Paris-Berlin 1815." In La Circulation des ouvres d'art-The Circulation of Works of Art in the Revolutionary Era, 1789-1848, edited by Roberta Panzanelli and Monica Preti-Hamard, 85-97. Rennes: Presses universitaires de Rennes, 2007.

Scolaro, Michela. "L'origine des musées égyptiens en Italie et en France." In Collections et marché de l'art en France 1789-1848, edited by Monica Preti-Hamard and Philippe Sénéchal, 349-58. Rennes: Presses universitaires de Rennes, 2005.

Scott, William Bell. Gems of French Art. London: George Routledge \& sons, 1871.

Scott, William Bell. Gems of Modern Belgian Art. London: George Routledge \& sons, 1872.

Scott, William Bell. Gems of Modern German Art. London: George Routledge \& sons, 1873 .

Sebag-Montefiore, Charles, and Julia I. Armstrong-Totten. A Dynasty of Dealers: John Smith and his Successors, 1801-1924. London: The Roxburghe Club, 2013.

Sécherre, Hélène. "Le marché des tableaux italiens à Paris sous la Restauration (18151830): collectionneurs, marchands, spéculateurs." In Collections et marché de l'art en France 1789-1848, edited by Monica Preti-Hamard and Philippe Sénéchal, 163-85. Rennes: Presses universitaires de Rennes, 2005.

Sharnova, Elena. “Un vrai musée de la peinture française': la collection française de Nicolaï Borissovitch Youssopov." In Collections et marché de l'art en France 1789-1848, edited by Monica Preti-Hamard and Philippe Sénéchal, 359-73. Rennes: Presses universitaires de Rennes, 2005.

Smith, Anthony D. National Identity. Reno: University of Nevada Press, 1993.

Smith, Anthony D. The Nation Made Real: Art and National Identity in Western Europe, 160o-1850. Oxford: Oxford University Press, 2013.

Stolwijk, Chris. Uit de schilderswereld. Nederlandse kunstschilders in de tweede helft van de negentiende eeuw. Leiden: Primavera, 1998.

Swanson, Vern G. The Biography and Catalogue Raisonné of the Paintings of Sir Lawrence Alma-Tadema. London: Garton, 1990.

Ten-Doesschate-Chu, Petra. "The $\mathrm{Lu}(\mathrm{c})$ re of London: French Artists and Art Dealers in the British Capital." In Monet's London: Artists' Reflections on the Thames 1859-1914, 39-54. Ghent: Snoeck, 2005. 
Ten-Doesschate-Chu, Petra. The Most Arrogant Man in France: Gustave Courbet and the Nineteenth-Century Media Culture. Princeton: Princeton University Press, 2007.

Teter, Patricia A. “English Gold, Corsican Brass, and French Iron': Opportunities for Collecting Art in Spain During the Napoleonic Wars." In La Circulation des ouvres d'art-The Circulation of Works of Art in the Revolutionary Era, 1789-1848, edited by Roberta Panzanelli and Monica Preti-Hamard, 309-21. Rennes: Presses universitaires de Rennes, 2007.

Thompson, Jennifer A. "Paul Durand-Ruel et l'Amérique." In Paul Durand-Ruel. Le pari de l'impressionisme, edited by Sylvie Patry, 106-19. Paris: Réunion des musées nationaux, 2014.

Thomson, Richard. "Theo van Gogh: An Honest Broker." In Theo van Gogh 1857-1891: Art Dealer, Collector and Brother of Vincent, edited by Chris Stolwijk and Richard Thomson, 61-148. Zwolle: Waanders, 1999.

Van Den Wijngaert, Frank. "De schilderkunst in de XIXde eeuw." In Bouwstoffen voor de geschiedenis van Antwerpen in de XIXde eeuw. Instellingen-economie-kultuur, 303-30. Antwerp: Lloyd Anversois, 1964.

Vanzype, Gustave. Les frères Stevens. Brussels: Nouvelle société d'éditions, 1936.

Verhoogt, Robert. Art in Reproduction: Nineteenth-Century Prints after Lawrence AlmaTadema, Jozef Israëls and Ary Scheffer. Amsterdam: Amsterdam University Press, 2007.

Verschaffel, Tom. "Art and Nationality: The French Perception of Belgian Painters at the Paris Salons (1831-1865)." In Visions/Revisions: Essays on Nineteenth-Century French Culture, edited by Nigel Harkness et al., 123-37. Oxford - Bern - Berlin: Peter Lang, 2003.

Vottero, Michaël. La Peinture de genre en France, après 1850. Rennes: Presses universitaires de Rennes, 2012.

Warner-Johnson, Tim, and Jeremy Howard. Colnaghi: Past, Present and Future: An Anthology. London: Colnaghi, 2016.

Westgarth, Mark. 'Florid-looking Speculators in Art and Virtu': The London Picture Trade c. 1850." In The Rise of the Modern Art Market in London, 1850-1939, edited by Pamela Fletcher and Anne Helmreich, 26-46. Manchester - New York: Manchester University Press, 2011.

White, Harrison C., and Cynthia A. White. Canvases and Careers: Institutional Change in the French Painting World. Chicago - London: The University of Chicago Press, 1993 .

Whiteley, Linda. "Art et commerce d'art en France avant l'époque impressionniste." Romantisme 13 (1983): 65-76. 